\title{
Delineation of spring recharge zones using environmental isotopes to support climate-resilient interventions in two mountainous catchments in Far-Western Nepal
}

\author{
Karthikeyan Matheswaran ${ }^{1} \cdot$ Ambika Khadka $^{2} \cdot$ Sanita Dhaubanjar $^{3}$ (D) Luna Bharati ${ }^{3} \cdot$ Sudhir Kumar $^{4} \cdot$ \\ Surendra Shrestha ${ }^{5}$
}

Received: 21 September 2018 / Accepted: 8 April 2019/Published online: 25 May 2019

(C) The Author(s) 2019

\begin{abstract}
Though springs are the primary source of water for communities in the mid-hills of Nepal, an in-depth scientific understanding of spring systems is missing, preventing the design of effective climate-resilient interventions for long-term sustainability of springs. This study marks the first attempt to combine environmental isotopes analysis with hydrometric and hydrogeological measurements to identify dominant recharge zones for springs in two mountainous catchments - Banlek and Shikarpur-in Far-Western Nepal. In total, 422 water samples collected from rainfall, springs and streams between March 2016 and March 2017 were analyzed for their isotopic composition $\left(\delta^{18} \mathrm{O}\right.$ and $\left.\delta \mathrm{D}\right)$. Isotopic composition of rainwater shows seasonality, suggesting that different sources of water vapor cause rains in monsoon and in dry season. Rainfall responses of individual springs were used to identify connections to unconfined and deeper groundwater strata. The isotopic composition of springs in the two catchments ranges from -9.55 to $-8.06 \%$ for $\delta^{18} \mathrm{O}$ and -67.58 to $-53.51 \%$ for $\delta \mathrm{D}$. The isotopic signature of the spring sources falls close to the local meteoric water line for the corresponding season, indicating strong rainfall contribution to springs. Altitudinal isotopic gradients suggest mean recharge elevation of 2,600-2,700 m asl for springs in Shikarpur, which lies beyond the surface-water catchment, and a recharge elevation of 1,000-1,100 m asl for Banlek, which partially extends beyond the surface-water catchment. The demarcated recharge zones will be used by government agencies to implement recharge interventions to increase the resiliency and reliability of springs in Far-Western Nepal.
\end{abstract}

Keywords Nepal $\cdot$ Stable isotopes $\cdot$ Artificial recharge $\cdot$ Climate change $\cdot$ Interventions

Sanita Dhaubanjar

sdhauban@gmail.com

1 Stockholm Environment Institute, 15th Floor, Witthyakit Building, 254 Chulalongkorn University, Chulalongkorn Soi 64, Phyathai Road, Pathumwan, Bangkok 1033, Thailand

2 Department of Built Environment, School of Engineering, Aalto University, Espoo, Finland

3 International Water Management Institute (IWMI), Shree Durbar Tole, Pulchowk 3, Lalitpur, Kathmandu, Nepal

4 National Institute of Hydrology, Indian Institute of Technology Roorkee, Roorkee, Uttarakhand 247667, India

5 Groundwater Resources Development Board, Babar Mahal, Kathmandu, Nepal

\section{Introduction}

Two-thirds of the global population are experiencing severe water scarcity at least 1 month of each year (Mekonnen and Hoekstra 2016), which is expected to be further aggravated by increasing demands and impacts of climate change (Palmer et al. 2008; Oki et al. 2014). Nepal has consistently ranked as one the most climate vulnerable countries globally because of increasing vulnerability to biophysical hazards and low capacity of local systems to absorb climate-induced shocks. The climate vulnerability exacerbates the condition of $25 \%$ of the people living below the poverty line and $66 \%$ of the population directly dependent on agriculture for sustenance (IDSNepal et al. 2014). Climate-change induced increase in temperature and uncertainties in precipitation are expected to have a direct bearing on water availability for agriculture and livelihood through changes in evapotranspiration, recharge 
magnitudes and discharge regimes. Water security is an imperative driver to achieve sustainable development, ensure economic sustenance and increase the climate resilience of rural vulnerable communities in Nepal, in which utilization of spring sources play a vital part (WECS 2011).

A climate vulnerability assessment for watersheds across Nepal identified the mid-hills in Western Nepal as the most vulnerable region within the country (Siddiqui et al. 2012). The mid-hills-elevation 1,000-2,500 m above sea level (asl) - in Nepal account for $45 \%$ of the total population, of which over $80 \%$ depend on agriculture and livestock for their livelihood (Dixit and Khadka 2013). The mean annual precipitation in Far-Western Nepal region is 1,921 mm, signifying adequate water resources availability; however, $80 \%$ of the annual rainfall arrives during the monsoon (June-September), leading to water scarcity in the drier months (October-May). Especially in Western Nepal, the inter-annual and seasonal climate variability is considered as the main determinant of food production, market access and commodity pricing (UNWFP 2014). Hence, for $80 \%$ of rural communities perched on hilltops far from river sources, springs are the primary source of water for sustaining domestic, agriculture and livestock water demands (Tambe et al. 2012; Sharma et al. 2016).

Decline in spring discharge has been reported in parts of India and in the Nepalese mid-hills due to increased water demand from changes in demographics, land use changes associated with agriculture and deforestation, and rainfall variability induced by climate change (Valdiya and Bartarya 1989; Negi and Joshi 1996; Negi and Joshi 2002; Merz et al. 2003; Tambe et al. 2012). As springs remain the main source of water for domestic and agricultural purposes, especially in dry periods, protecting their source areas and introducing interventions to manage them is critical for ensuring water and livelihood security in the region. However, data and knowledge of local meteorology, hydrology, geology, and surface-water/groundwater dynamics, imperative to designing climate resilient interventions for spring management, are scarce for the Nepalese midhills. The lack of understanding of fundamental processes governing springs in the hydrogeologically complex and ungauged Himalayan catchments is a key reason for limited impact, or even failure, of watershed interventions (Sharma et al. 2000; Government of Sikkim 2014; Vashisht 2008).

Identifying dominant spring recharge zones is a prerequisite for successful management and augmentation of springs through a suite of potential interventions such as infiltration structures (ponds and trenches) and land management activities to sustain water availability and reliability (Kresic and Bonacci 2010). Depending on the objectives and scale of the intended study, appropriate choice of physical, tracer and numerical modeling-based methods can be used to delineate and estimate groundwater recharge (Scanlon et al. 2002; Chowdhury et al. 2010; Chinnasamy and Prathapar 2016). The combination of geophysical investigations, hydro- geochemistry and naturally existing tracers - the environmental isotopes $\left({ }^{2} \mathrm{H},{ }^{18} \mathrm{O}\right.$ and $\left.{ }^{3} \mathrm{H}\right)$ - can provide critical insights into the spatial distribution of groundwater aquifers and their recharge areas (Clark and Fritz 1997). To understand the groundwater recharge dynamics in data-scarce, small, ungauged mountain catchments, tracers (natural and artificial) and geophysical methods have been widely used to identify groundwater residence time and to locate recharge zones (Stimson et al. 1993; Mathieu and Bariac 1996; Chinnasamy and Prathapar 2016). The environmental isotopes of oxygen and hydrogen isotopes $\left(\delta^{18} \mathrm{O}\right.$ and $\left.\delta \mathrm{D}\right)$ have been used to determine recharge mechanisms, trace the origin of spring systems, and estimate residence time of groundwater in the Himalayan region (Jeelani et al. 2010). The $\delta^{18} \mathrm{O}$ and $\delta \mathrm{D}$ isotopic composition of rain samples collected at different altitudes and latitudes along the hillslope exhibit different isotopic signatures, which contribute to the creation of a local meteoric water line (LMLW; Gat 1971; Clark and Fritz 1997; Price and Swart 2006; Fontes et al. 1967; Jeelani et al. 2010; Kumar et al. 2010a; Fetter 2001). Dominant recharge elevations contributing to spring flow can be identified by relating the isotopic signature of spring sources to altitudinal gradient for $\delta^{18} \mathrm{O}$ and $\delta \mathrm{D}$ in rainfall and comparing to that LMLW. Evaporation and mixing of recharged water with groundwater from various sources can, however, affect the isotopic signature of springs leading to its departure from the LMWL (O'Driscoll et al. 2005).

A sizeable number of stable isotope applications for spring hydrology have been carried out on the Indian side of the Western Himalayan range (Jeelani et al. 2010, 2015, 2017; Shah et al. 2017). Kumar et al. (2010a) also analyze the stable isotopic ratios in precipitation for India while Kumar et al. (2010b) investigated the isotopic characteristics of precipitation in the Kumaon Himalayas located close to the IndiaNepal border in the West. Previous environmental isotope studies within Nepal focused on estimating the relative contribution of various water sources to the stream, but have not been applied for delineation of spring recharge areas (Ramesh and Sarin 1992; Garzione et al. 2000; Racoviteanu et al. 2013). More recently, Wilson (2015) and Florea et al. (2017) characterize isotopic compositions in surface and groundwater in Langtang (central) and Everest (eastern) regions of Nepal; however, to the authors' knowledge, this study is the first isotopic analysis conducted with a specific focus on spring systems in Far-Western Nepal.

This study utilizes stable isotopes of $\delta^{18} \mathrm{O}$ and $\delta \mathrm{D}$ in rainfall, springs and stream water to delineate spring recharge zones to support the design of evidence-based climate resilient interventions in two mountainous catchments (Banlek and Shikarpur) located in Far-Western Nepal. This study is a part of the Government of Nepal's Building Climate Resilience of Watersheds in Mountain Eco-Regions (BCRWME) project under its Strategic Program for Climate Resilience, which 
aims to build climate resiliency of vulnerable mountain communities. The BCRWME project, led by the Department of Forest and Soil Conservation (DFSC), previously Department of Soil Conservation and Watershed Management (DSCWM), is implementing watershed management interventions to sustain spring water availability in many mountain watersheds in Far-Western Nepal, under changing climate conditions. The isotope-based recharge zone delineation will form the basis for gauging the suitability and siting of potential interventions such as afforestation, on-farm conservation, infiltration trenches, recharge ponds, small storage tanks, bioengineering, gully protection, and social fencing, to sustain springs and provide food and livelihood security to these mountain communities.

\section{Materials and methods}

\section{Study area}

Two pilot springsheds (Fig. 1a,b) - Shikarpur and Banlek, within the West Seti River basin-were chosen from 108 sites under the BCRWME project to use environmental isotopes for spring recharge zone delineation. Key characteristics of these two catchments are presented in Table 1. Around 75 households in Shikarpur use three springs for domestic and agriculture purposes, and for operating a 3-kW micro-hydropower plant (Okwany and Khadka 2016). In Banlek, there are two well-defined channels with four springs primarily used for drinking purposes and for livestock and irrigation on the rare occasion when excess water is available (Okwany and Khadka 2016). The slope largely faces northeast and east, with aspect ranging from 23 to $113^{\circ}$ (with $0^{\circ}$ being north, $180^{\circ}$ being south), which indicates that most runoff will head in that direction.

\section{Hydrogeology}

For Shikarpur and Banlek, site specific geological data are not available. Based on information obtained from the regional geological map, the field visits and expert judgement, the local hydrogeology of these two springsheds is described. A base map of 1:50,000 scale was first prepared using a topographic map published by the Survey Department, Nepal, Topo Sheet no. 2980 15B for Banlek area and Topo Sheet no. 2980 11B for Shikharpur. A geological traverse was carried out along the stream, road cut sections and foot trials to obtain geological and hydrogeological information like rock and soil type, dip strike measurement of discontinuities, weathering conditions, geological structures and occurrence and nature of springs. The hydrogeology of the two pilot springsheds is presented in Fig. 2a,c) along with the geological cross section across the selected transect Fig. 2b,d).

\section{Shikarpur}

The geology in Shikarpur consists of fine-grained gray limestone from Lakherpata Formation overlaying calcareous quartzite and dolomitic limestone from Syanga Formation. In the upper slopes, the limestone appears highly fractured and crushed, and in some areas, small caves are visible indicating karst topography with subsurface caverns. The limestones have three joint sets and random fractures forming wedge shape blocks. The joints are close spaced and have smooth to rough surfaces. The attitude of the bedding plane has SW-NE strike with NW dipping at $24-41^{\circ}$. This formation is correlated with the Lakharpata Formation of the regional geological map of Far-Western Nepal. The southern part of the study area consists of quartzite and phyllite. The quartzite observed along the road cut section is medium to thickly foliated, highly fractured and moderately weathered, and gray colored. Chlorides, quartz and feldspar dominate the mineral composition of the rock. Dark gray to purple colored phyllite and phyllitic slates are also present within the quartzite with three joint sets and random fractures forming wedge shape blocks. The joints are close spaced and have smooth to rough surfaces. The foliation plane has a SW-NE strike with NW dipping at $10-30^{\circ}$. This quartzite and phyllite are correlated with the Syanga Formation of the geological map of Far Western Nepal. Colluvial deposits, composed of angular fragments of quartzite, limestone and phyllite, are very widely disturbed within the watershed area along the lower part of the slope and form the unconfined stratum in the area. Most of the joint sets in the Shikarpur Springshed have continuous close to tight joints, rough and irregular surfaces, and show a high degree of intersection of discontinuities.

\section{Banlek}

Similar to Shikarpur, colluvial deposits are widely distributed within the Banlek springshed area (Fig. 2c,d). These deposits are composed of angular fragments of quartzite and phyllite with angular fragments. At the middle part of the catchment area, an old landslide was observed also containing the same colluvial deposits. The geology consists of metasedimentary rocks of grey colored, medium to coarse grained, highly fractured quartzite and thinly bedded undulated phyllite. The bedrocks are mostly exposed along the stream cut section, road cut section and at some cultivated areas of contoured terrace. The joints are closely spaced and have smooth to rough surfaces. The bedding plane has NW-SE strike with $38-68^{\circ} \mathrm{SW}$ dipping. Banlek area is situated in the north of the Main Boundary Thrust which lies about $25 \mathrm{~km}$ south from the study area. Foliation structures in quartzite and phyllite are distinct and common in the investigated site. Foliation controls the general geography of the area. The thickness of the foliation varies from thin $(<10 \mathrm{~cm})$ to thick $(>1 \mathrm{~m})$. The foliation plane 


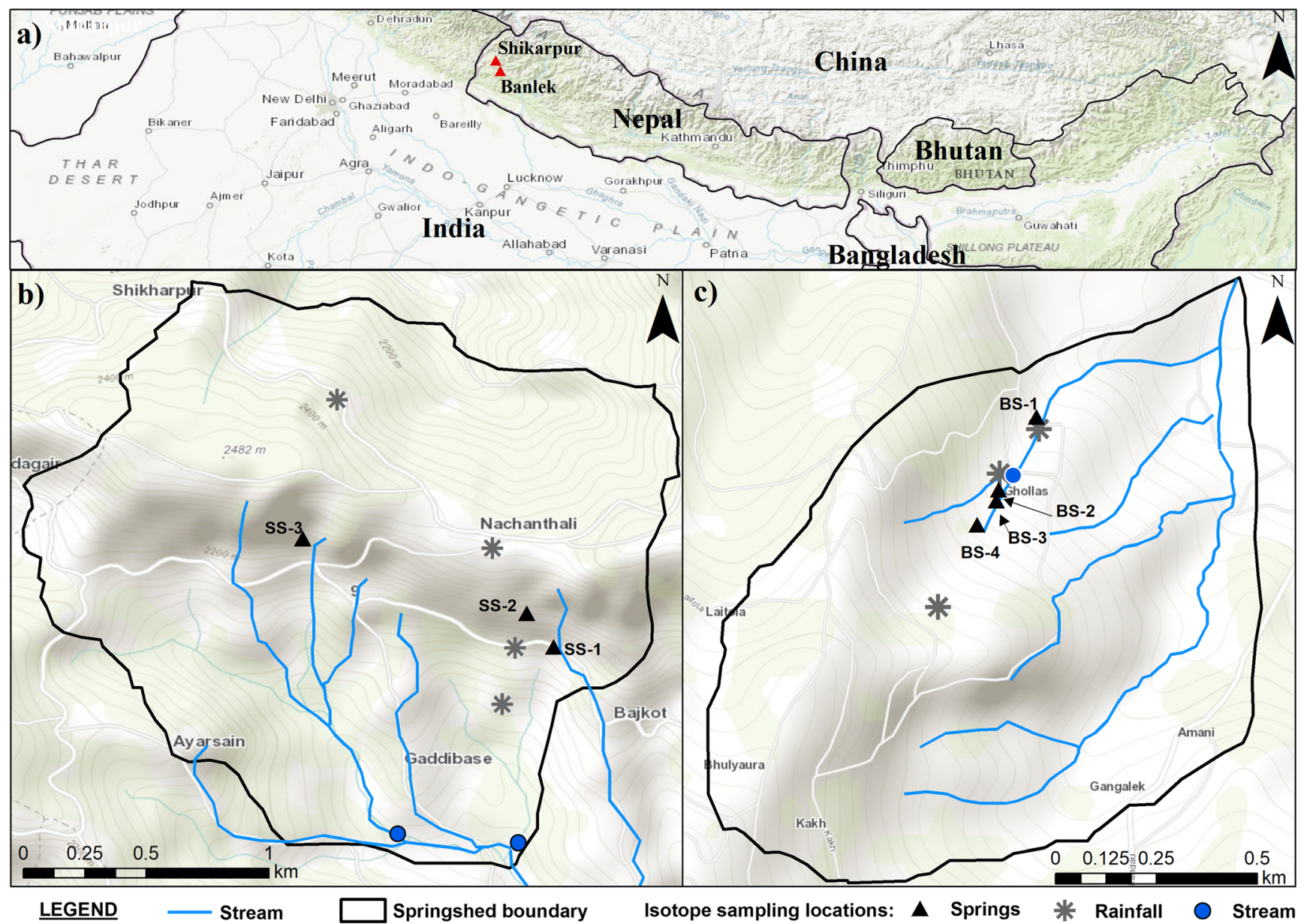

Fig. 1 a Location of the two pilot springsheds in South Asia, b Shikarpur and $\mathbf{c}$ Banlek in Far-Western Nepal showing the catchment boundary, and isotope sampling sites. Springs are numbered and denoted in relation to their catchments. SS Shikarpur spring; BS Banlek spring

in the area is dipping towards the south to south-west, with dip amount varying from 45 to $78^{\circ}$. Some quartz veins are also observed along the foliation planes. In both catchments, rock exposures show a high degree of intersection and discontinuities which determines the degree of anisotropy of groundwater flow in the fracture network, as such a high degree of interconnection facilitates smooth and uniform groundwater flow.

\section{Hydro-meteorological measurements}

Two automatic weather stations were installed in October 2015 to capture site-specific weather phenomena consisting of rainfall, temperature, relative humidity, solar radiation, and wind speed. The automatic rain gauge in the Banlek catchment malfunctioned during the 2016 observation period resulting in reliable observations only from Jan 2017. Meanwhile, the observations in Shikarpur are available from November 2015 till November 2017. Two v-notch weirs were installed, one in each catchment in April 2016 to estimate discharge based on water level recorded above the v-notch using an automatic pressure sensor. The automatic measurements were collected at sub-daily timescales and aggregated to daily averages. Spring sources are additionally measured manually once every morning using the time-volume method.

\section{Isotope sampling}

Water samples from three springs, two streams, and rainfall at four elevations were collected from Shikarpur, while similarly, a sample from four springs, one stream, two points in West Seti River and rainfall at three elevations were collected in Banlek. The isotope sampling locations are shown in Fig. 1. During the monsoon season (June-September), samples from springs and streams were collected weekly while during dry season, comprising the winter and summer months (October-May), samples were collected fortnightly. Rainfall water samples or snow samples were collected for all events greater than $5 \mathrm{~mm}$. Note that Western Nepal is known to also receive rains in the winter (Bookhagen and Burbank 2010). The water sample collection 
Table 1 Key characteristics of two pilot catchments in Far Western Nepal

\begin{tabular}{|c|c|c|}
\hline $\begin{array}{l}\text { Catchment } \\
\text { characteristic }\end{array}$ & Shikarpur & Banlek \\
\hline Area $\left(\mathrm{km}^{2}\right)$ & 3.74 & 1.74 \\
\hline Elevation (m asl) & $1,812-2,470$ & $770-1,215$ \\
\hline Slope $(\%)$ & $0.8-62$ & $5.8-48.4$ \\
\hline $\begin{array}{l}\text { Number of springs } \\
\text { and their elevations }\end{array}$ & 3 (at $1,687 \mathrm{~m}, 1,688 \mathrm{~m}$ and $2,166 \mathrm{~m})$ & 4 (at $700 \mathrm{~m}$, two sources at $800 \mathrm{~m}$, and $850 \mathrm{~m}$ ) \\
\hline Land cover & $\begin{array}{l}\text { Agriculture } 30 \% \text {; forest } 27 \% \text {; grassland } 18 \% \text {; shrubland } 4 \% \text {; } \\
\text { settlements } 1.5 \%\end{array}$ & Forest $38 \%$; agriculture $27 \%$; barren land $20 \%$; settlements $7 \%$ \\
\hline Geological stratum & $\begin{array}{l}\text { Top layer: fine-grained gray limestone and dolomitic } \\
\text { limestone. } \\
\text { Bottom layer: white, pale orange or pinkish calcareous } \\
\text { quartzite and dark-gray-colored dolomitic limestone }\end{array}$ & $\begin{array}{l}\text { Top layer: gray phyllite. } \\
\text { Bottom layer: white quartzites alternating with thin phyllites and } \\
\text { calcareous quartzite }\end{array}$ \\
\hline $\begin{array}{l}\text { Proposed } \\
\text { interventions }\end{array}$ & Social fencing, piped diversion, and conservation & $\begin{array}{l}\text { Afforestation, grazing management, gully protection, on-farm } \\
\text { conservation, recharge ponds, and source protection }\end{array}$ \\
\hline
\end{tabular}

and lab analysis of isotopic compositions were conducted from August 2015 to March 2017. In total, 422 water samples were collected and analyzed for $\delta^{18} \mathrm{O}$ and $\delta \mathrm{D}$ by Dual Inlet Isotope Ratio Mass Spectrometer (Isoprime with Masslynx software Ver. 4.0) at the Stable Isotope Laboratory (Nuclear lab) at National Institute of Hydrology in Roorkee, India. The stable isotope composition of oxygen and hydrogen are reported using conventional delta $(\delta)$ notation (Craig 1961), $\delta^{18} \mathrm{O}$ and $\delta \mathrm{D}$ in per mil (\%o) relative to Vienna Standard Mean Ocean Water, VSMOW (Gonfiantini 1981). The precision of the measurement of $\delta^{18} \mathrm{O}$ and $\delta \mathrm{D}$ was \pm 0.1 and $\pm 1.0 \%$, respectively. Deuterium excess, $d-$ excess, (Dansgaard 1964) was calculated using the standard equation:

$\mathrm{d}-$ excess $=\delta \mathrm{D}-8 \delta^{18} \mathrm{O}$

\section{Results}

\section{Rainfall patterns and the effect on spring flows}

Daily rainfall magnitude and spring flow observed in the two study catchments are presented in Fig. 3a (Shikarpur) and Fig. $3 \mathrm{~b}$ (Banlek). The total observed rainfall from January to August 2017 was 2,025 mm in Shikarpur and $925 \mathrm{~mm}$ in Banlek (Fig. 3a,b). During the 2017 observation period, the total rainfall observed in Shikarpur was twice that of the Banlek catchment. The contribution of the monsoon, driven by the winds from the Bay of Bengal, to the total rainfall in 2017 stands at $81 \%$ in Shikarpur $(1,781 \mathrm{~mm})$ and $74.3 \%$ in Banlek catchments $(688 \mathrm{~mm})$. In 2016, the Southwest monsoon contribution in Shikarpur catchment was $1,778 \mathrm{~mm}$, which is $83.7 \%$ of the total annual rainfall received. The maximum 1-day precipitation observed in Shikarpur is $128.6 \mathrm{~mm}$ and Banlek is $79.8 \mathrm{~mm}$. While the observation period covers
2 years in Shikarpur and less than a year in Banlek, it is evident from the 2017 data that both catchments exhibit different rainfall patterns owing to micro-climates fueled by local convective and orographic interactions common in the Himalayan region.

Mean daily discharge of 182,176 and $51 \mathrm{~L} / \mathrm{min}$ were observed in the three Shikarpur springs between November 2015 and 2017. In Banlek, the observed daily mean discharge estimated over the same observation period was 5, 6.6 and $7 \mathrm{~L} /$ min. Shikarpur is located in a larger mountain range with twice as much rainfall as Banlek, resulting in such higher magnitude of spring flows. Out of the three springs monitored in Shikarpur catchment, two springs (SS-1 and SS-2) respond quickly to rainfall events, while the response from the spring SS-3 was relatively lower (Fig. 3a). Similarly, spring BS-2 and BS-3 in Banlek catchment show quick responses to rainfall events. The relatively stable nature of spring hydrographs in BS-1 and BS-4 in Banlek, and SS-3 in Shikarpur, indicates a year-round contribution from stable groundwater sources. The spring hydrographs shown in Fig. 3 indicate that the onset of increase in spring flows coincides with the occurrence of the Southwest monsoon. The rising limb of spring hydrographs in Shikarpur occurs during the first week of July, while it was observed to occur during late August/early September in Banlek. Discharge in Banlek declined significantly in 2017 and field observations confirmed that the site was facing a drought with a decline in rainfall as well as spring flows throughout the catchment.

Based on the time difference in measured rainfall peak and observed peak flow in spring flows, 10 days was estimated as an approximate time taken for the rainfall response to appear in the springs in Shikarpur. Owing to limited rainfall data in Banlek catchment, residence time was not estimated; however, considering the smaller catchment size, moderate slopes, and more infiltration-related hydrogeological characteristics, it is likely that the mean residence time will be less than 

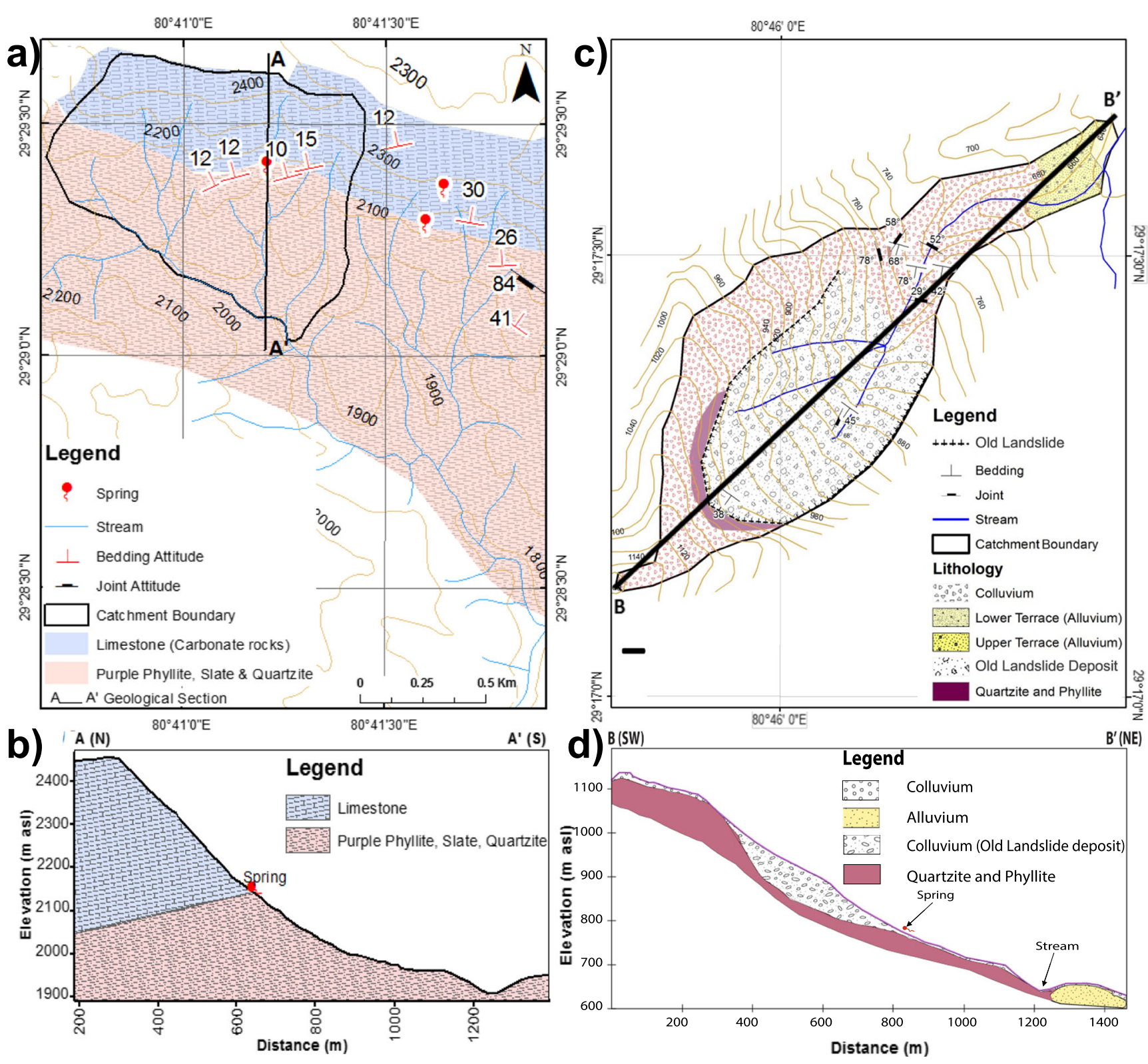

Fig. 2 Hydrogeological setting. a Shikarpur geological map, b Cross section profile of Shikarpur along $\mathrm{AA}^{\prime}$ transect, $\mathbf{c}$ Banlek geological map and $\mathbf{d}$ cross sectional profile of Banlek along $\mathrm{BB}^{\prime}$ intersect. Both

catchments contain weathered quartzite and phyllite formation dominating the subsurface stratum. Note that thickness of formations are not to scale

10 days for springs fed by rainfall recharge. These hydrometric observations in springs in Banlek and Shikarpur indicate that BS-2, BS-3, SS-1, and SS-2 derive water from unconfined groundwater sources with larger recharge areas, which explains the immediate response to rainfall events. The remaining springs did not show such response to rainfall events, indicating that these springs are possibly fed by deeper groundwater sources with longer residence time or with smaller recharge areas. Identifying the nature of springs and the key hydrogeologic drivers has a direct bearing on design of climate resilient interventions.

\section{Intra and inter-seasonal variations of $\delta^{18} 0$ and $\delta D$ in rainfall and springs}

A summary of $\delta^{18} \mathrm{O}$ and $\delta \mathrm{D}$ composition of the rainfall and spring water samples in the two catchments is presented in Table 2. The rainfall samples collected in two seasons, monsoon (June-September) and dry season (October-May), showed two distinct isotopic signatures. In Shikarpur, intraseasonal variations of $\delta^{18} \mathrm{O}$ in Southwest monsoon rainfall samples, standard deviation $(\mathrm{SD})=2.66$, were substantially lower than the variations observed in winter season samples 
Fig. 3 Observed daily rainfall and spring discharge in a Shikarpur and $\mathbf{b}$ Banlek
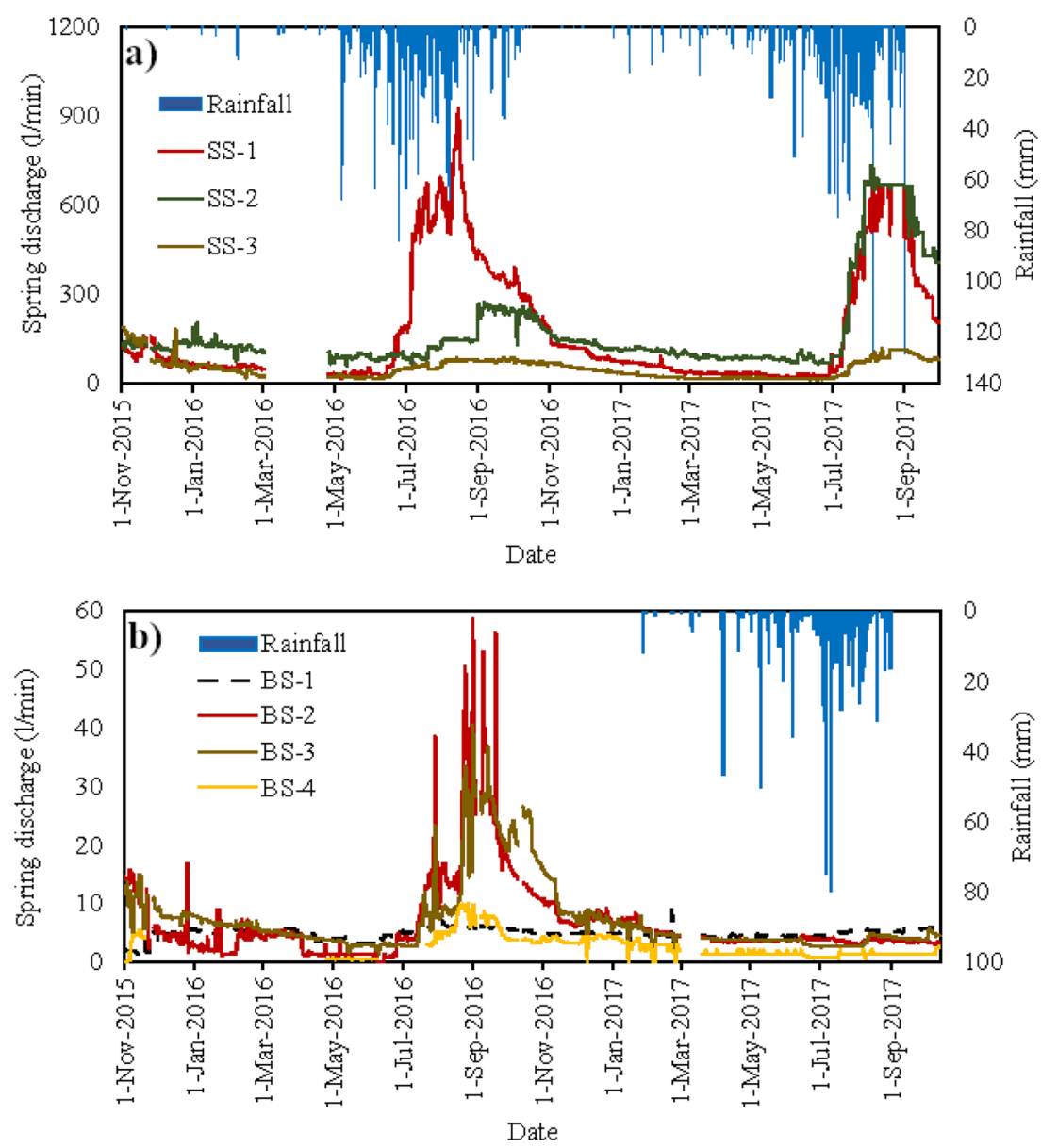

$(\mathrm{SD}=6)$. In the case of measured $\delta \mathrm{D}$, this phenomenon is reversed with dry season samples showing lower intraseasonal variations $(\mathrm{SD}=3.96)$ compared to Southwest monsoon rainfall events $(\mathrm{SD}=31)$. In Banlek, seasonal variations for both $\delta^{18} \mathrm{O}$ and $\delta \mathrm{D}$ were pronounced during the Southwest monsoon season compared to dry season samples. The Southwest monsoon rainfall samples collected in Shikarpur are more depleted of heavier isotopes (mean $\delta^{18} \mathrm{O}:-11.54$ and $\delta \mathrm{D}:-82.64 \%$ ) than the samples from Banlek, which is reasonable, as the latter is located at lower elevation $\left(\delta^{18} \mathrm{O}\right.$ :

Table 2 Summary of stable isotope analysis $\left(\delta^{18} \mathrm{O}\right.$ and $\left.\delta \mathrm{D}\right)$ from the two catchments (Shikarpur and Banlek). For Shikarpur, samples were collected from March 2016 to March 2017 and for Banlek from August 2015 to September 2016

\begin{tabular}{|c|c|c|c|c|c|c|c|c|c|c|}
\hline \multirow[t]{2}{*}{ Catchment } & \multirow[t]{2}{*}{ Source } & \multirow[t]{2}{*}{ No. of samples } & \multicolumn{4}{|c|}{$\delta^{18} \mathrm{O}(\% \circ)$} & \multicolumn{4}{|l|}{$\delta \mathrm{D}(\%)$} \\
\hline & & & Min & Max & Mean & SD & Min & Max & Mean & SD \\
\hline \multirow[t]{5}{*}{ Shikarpur } & Rain (monsoon) & - & -17.73 & -5.33 & -11.54 & 2.66 & -130.62 & -38.21 & -82.64 & 21.90 \\
\hline & Rain (dry) & - & -11.67 & 2.69 & -2.89 & 6.05 & -80.91 & 22.97 & 16.52 & 3.91 \\
\hline & Spring SS-1 & 25 & -9.10 & -8.72 & -8.93 & 0.09 & -63.28 & -53.51 & -59.77 & 1.88 \\
\hline & Spring SS-2 & 26 & -9.31 & -8.06 & -8.94 & 0.25 & -63.35 & -55.38 & -61.03 & 1.77 \\
\hline & Spring SS-3 & 26 & -9.51 & -8.99 & -9.17 & 0.11 & -64.82 & -56.75 & -62.06 & 1.61 \\
\hline \multirow[t]{6}{*}{ Banlek } & Rain (monsoon) & - & -12.85 & -5.27 & -9.17 & 2.17 & -94.78 & -29.05 & -66.47 & 16.80 \\
\hline & Rain (dry) & - & -3.68 & -3.56 & -3.60 & 0.07 & -15.24 & -14.41 & -14.82 & 0.42 \\
\hline & Spring BS-1 & 15 & -9.10 & -8.64 & -8.96 & 0.13 & -64.48 & -59.75 & -62.51 & 1.50 \\
\hline & Spring BS-2 & 16 & -9.37 & -8.94 & -9.19 & 0.13 & -66.74 & -62.20 & -64.57 & 1.23 \\
\hline & Spring BS-3 & 9 & -9.55 & -9.01 & -9.25 & 0.18 & -67.58 & -63.38 & -65.47 & 1.44 \\
\hline & Spring BS-4 & 12 & -9.33 & -8.80 & -9.14 & 0.16 & -65.93 & -63.44 & -64.65 & 0.73 \\
\hline
\end{tabular}


-9.17 and $\delta \mathrm{D}:-66.47 \%$ ). However, the isotopic composition observations from winter rainfall samples do not follow the same elevation-dependent isotopic depletion trend.

The isotopic composition of seven springs in the two catchments exhibits similar magnitude of $\delta^{18} \mathrm{O}(-9.5$ to $-8.9 \%$ ) and $\delta \mathrm{D}(-67$ to $-56 \%$ o $)$ within a narrow range. The maximum standard deviation of $0.25 \%$ was observed in SS-2 in Shikarpur and the variations of $\delta^{18} \mathrm{O}$ in other springs were less than $0.18 \%$, whereas in case of $\delta \mathrm{D}$ composition among the springs, the variations are less than $1.8 \%$. The strong inter-seasonal variations in isotopic composition observed in rainfall samples were not reflected in the spring observations in both catchments. There is loss of seasonal variations during infiltration through the unsaturated zone (Clark and Fritz 1997).

In the Shikarpur catchment, the onset of monsoon caused a visible spike in isotopic composition of rainfall samples (from nearly -14 to $-6 \%$ of $\delta^{18} \mathrm{O}$ and -104 to $-42 \%$ or for $\delta \mathrm{D}$ in the secondary axis for Fig. 4), which is still lower than the 1.45 for $\delta^{18} \mathrm{O}$ and 32.47 for $\delta \mathrm{D}$ measured during dry season months. The enrichment peak caused by the onset of monsoon subsided rapidly within the span of 17 days. The spring water samples were also enriched in heavier isotopes during Southwest monsoon months (July-August); however, the higher enrichment of heavier isotopes observed in dry season rainfall samples was not reflected in spring samples that appear depleted. In Shikarpur catchment, the lowest values in the spring water samples were observed during the months of April-May. The absolute values of isotopic composition observed in Banlek follow a similar profile to that of Shikarpur, but the absence of measurements during the in-between months forms a poor basis to derive any inference on specific trends from the intermittent time series data. More continuous sampling is needed in Banlek to deduce intra and inter-seasonal trends in the isotopic composition of the rainfall and spring water especially because the relatively lower number of rain events in Banlek limited the number of rainfall samples that could be gathered.

\section{LMWL}

A linear relationship between $\delta^{18} \mathrm{O}$ and $\delta \mathrm{D}$ for the rainfall samples was used to derive the LMWL for Shikarpur and Banlek catchments (Fig. 5 and Eqs. 2 and 3).

$$
\begin{aligned}
& \text { Shikarpur LMWL }: \delta \mathrm{D}=8.4803 \delta^{18} \mathrm{O}+15.573 \\
& \text { Banlek LMWL }: \delta \mathrm{D}=7.6372 \delta^{18} \mathrm{O}+4.1226
\end{aligned}
$$

The LWML for the two catchments were compared with the global meteoric water line (GMWL) (Craig 1961; Rozanski and Araguas-Araguas 1993) given by

GMWL $: \delta \mathrm{D}=8.17 \delta^{18} \mathrm{O}+10.35$
The slope and intercept of the Shikarpur LMWL are in close agreement with the GMWL, while the Banlek LWML significantly differs in both slope and intercept. In addition, the distinct isotopic signature of winter rainfall events in Shikarpur located at higher elevation compared to Banlek is clearly evident from Fig. 5a. The rainfall events recorded in Shikarpur during winter season showed significant enrichment of both $\delta^{18} \mathrm{O}$ and $\delta \mathrm{D}$ isotopes. A low number of rainfall events recorded in Banlek did not show the observed seasonality in Shikarpur isotopic signature in monsoon and dry season (Fig. 5b,d). Due to this, a separate LMWL was created for Southwest monsoon (July 2016 to October 2016) for both catchments. The resultant Shikarpur and Banlek LMWLs for Southwest monsoon follow GMWL with a slope of 8.1746 and intercept of 11.703 for Shikarpur (Fig. 5b), and slope of 8.177 and intercept of 8.9882 for Banlek (Fig. 5d). The resultant values of the LMWL are however different to the LMWL from the nearest International Atomic Energy Agency's (IAEA) Global Network of Isotopes in Precipitation (GNIP) station in New Delhi, India (Datta et al. 1991), given by

Delhi LMWL : $\delta \mathrm{D}=6.8 \delta^{18} \mathrm{O}+0.7$

The significance of evaporation effects on the isotopic ratio of rainwater in low-altitude semi-arid conditions prevalent in Delhi could explain the significant difference between LMWL derived for Delhi and Western Nepal catchments in this study (Eqs. 1, 2 and 4). This reiterates the complex association between $\delta^{18} \mathrm{O}$ and $\delta \mathrm{D}$ in samples derived from the monsoonal rainfall events and the impact of local effects on isotopic compositions. The isotopic signature of springs in Banlek and Shikarpur catchments lie close to the LMWL of respective catchments (Fig. 6), indicating strong rainfall contribution to infiltration. Even the isotopic signature of springs SS-3, BS-1 and BS-4, which show lower and delayed response to the rainfall events compared to other spring sources in both the catchments, lies closer to the respective LWML.

\section{Deuterium excess}

Deuterium excess (d-excess) estimated from rainfall samples serves as a tool to trace the water vapor source region even across continents, including the nature of the air mass and meteorological conditions at the vapor source regions (Gat et al. 1994). The global mean value of d-excess is approximately $+10 \%$ o (Froehlich et al. 2002; Rozanski and AraguasAraguas 1993). In this study, the d-excess ranged between 7.44 and $22.97 \%$ in Shikarpur and 7.76 and $14.01 \%$ in Banlek during the sampling period (Table 3; Fig. 7). Lower temperature and humidity values in the water vapor source region for rainfall may yield such large d-excess values. Evidence of such rainfall sourced from western disturbances contributing to spring recharge in the Western Himalayas has been found in previous studies (Jeelani et al. 2015, 2017). 


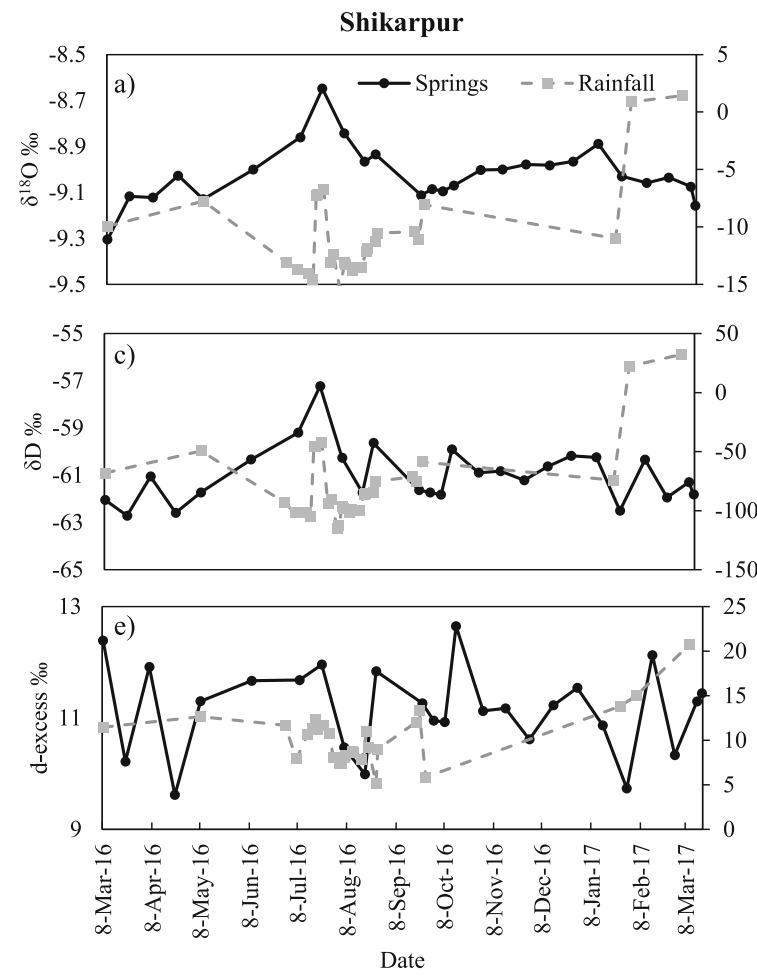

Fig. 4 Temporal variation of $\delta^{18} \mathrm{O}(\mathbf{a}-\mathbf{b}), \delta \mathrm{D}(\mathbf{c}-\mathbf{d})$ and d-excess $(\mathbf{e}-\mathbf{f})$ in rainfall and springs in Shikarpur and Banlek catchment. Rainfall samples are plotted in the secondary $y$-axis. The values are aggregated at the

The d-excess in both catchments also exhibits strong seasonal and altitudinal variation. The d-excess in rainfall was 60 and $71 \%$ higher during the dry season compared to the samples from the monsoon season in Shikarpur and Banlek respectively. Except for the sampling period of July and August 2016, the lowest elevation of rainfall sampling $(1,954 \mathrm{~m})$ in Shikarpur provided the highest d-excess values. In the case of Banlek, no definite trends emerge in the monsoon season. The

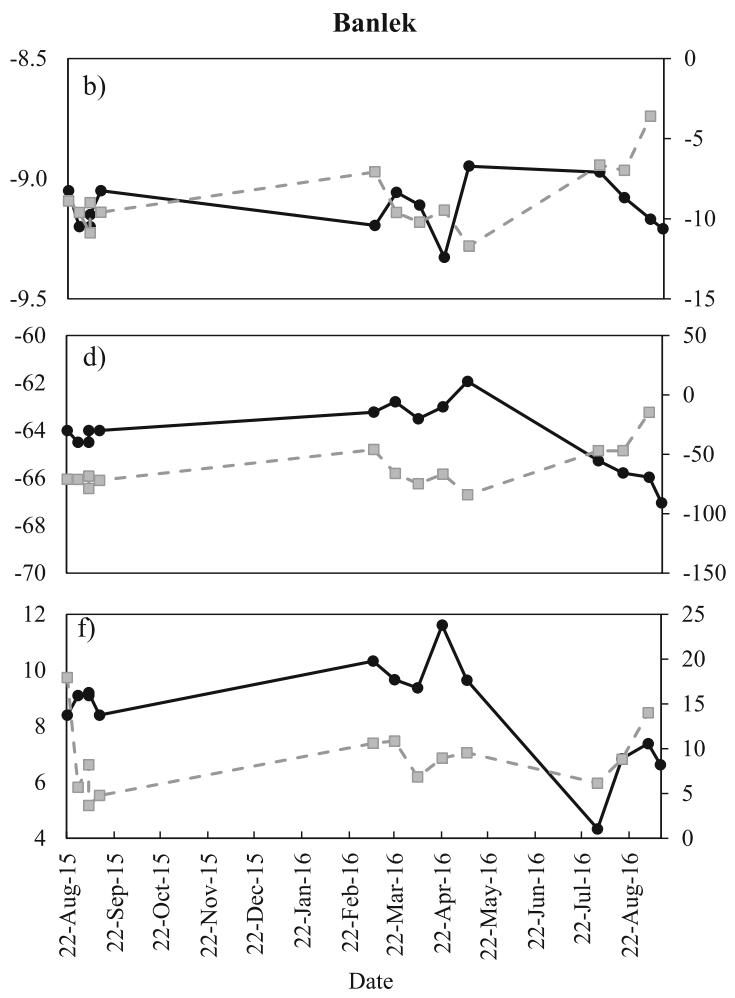

catchment scale by averaging rainfall and spring samples for each catchment

lowest elevation rainfall sample site of $733 \mathrm{~m}$ provides the highest d-excess value (14.23\%o) in January 2017; however, in Banlek, the dry season rain events were only observed in the month of January 2017. Due to the lower altitude of Banlek compared to Shikarpur, it is envisaged that the difference in seasonal d-excess values will be higher during later months in the dry season. In Shikarpur, rainfall in the summer month of March 2017 showed the highest d-excess in the
Fig. 5 Comparison of the local meteoric water line (LWML) derived from isotope composition data for rainfall with the global meteoric water line (GWML; from Craig 1961; Rozanski and Araguas-Araguas 1993) for: a-b. All rainfall samples for Shikarpur and Banlek catchment, respectively, and $\mathbf{c}-\mathbf{d}$ Southwest Monsoon samples in Shikarpur and Banlek, respectively
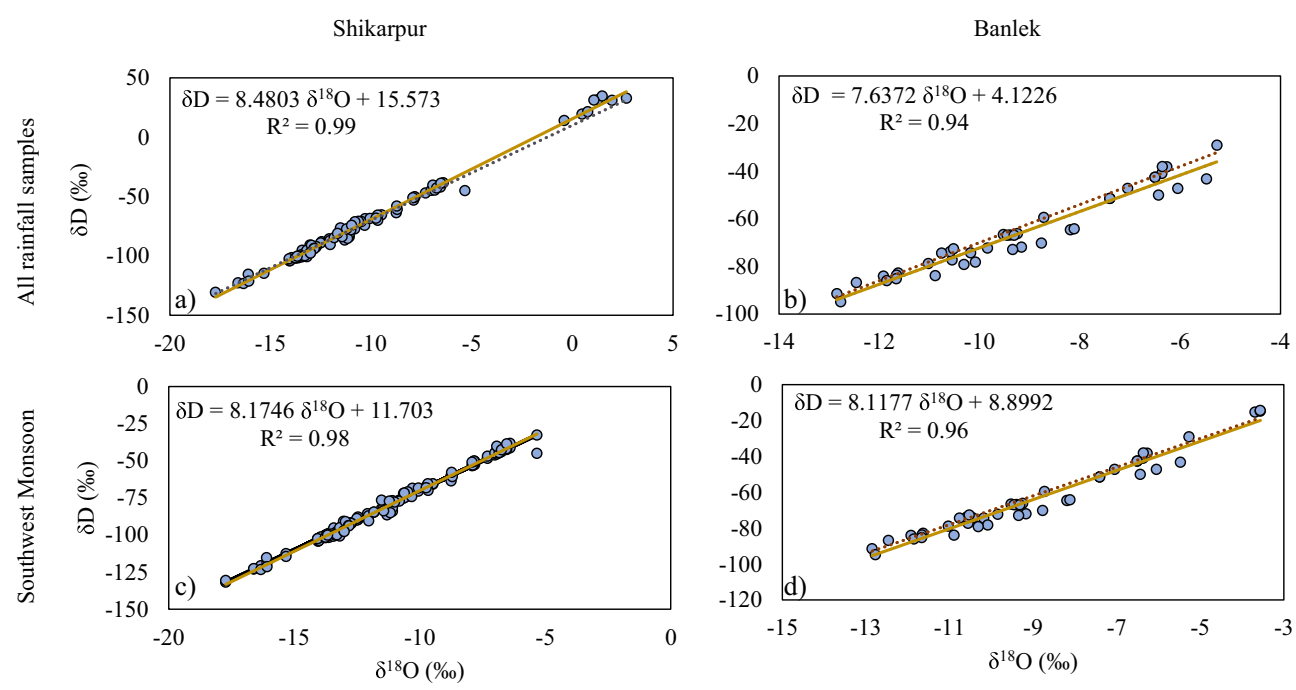

GMWL LMWL 
Fig. 6 Comparison of isotope composition for water samples from springs with the LWML derived from all rainfall samples in a Shikarpur and b Banlek
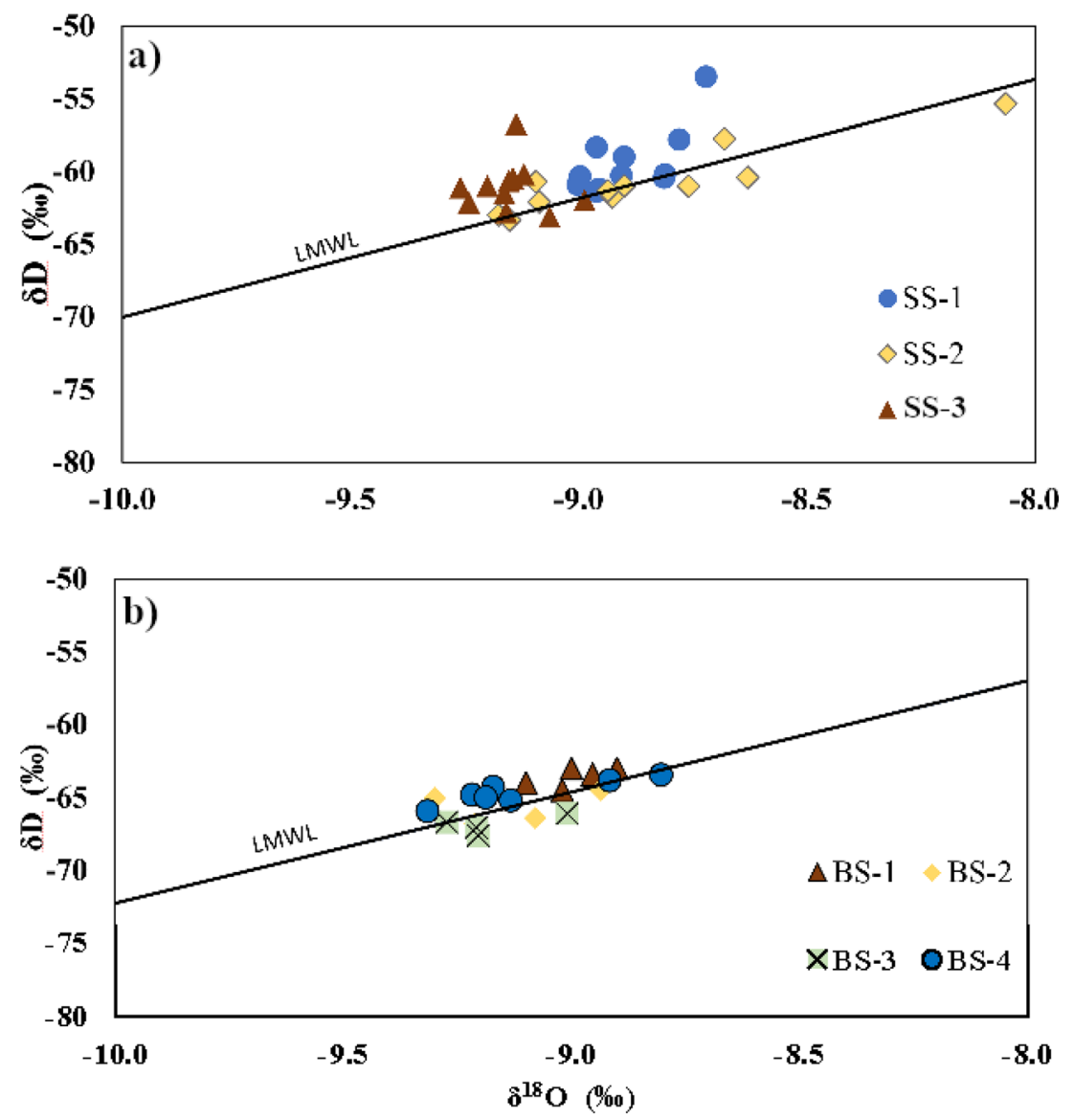

range of $19.98 \%$ followed by $16.18 \%$ in February 2017 and $14 \%$ in January 2017, while in contrast, d-excess estimated in the monsoon months between June and October 2016 were nearly half, ranging from 8.13 to $10.93 \%$. Such large variations in d-excess for the dry season rainfall events have previously been attributed to the water vapor for the rain being derived from possible inland sources (Kumar et al. 2010a).

Secondary evaporation is another factor affecting the dexcess estimates, particularly in low altitude zones (Jeelani et al. 2017). During the monsoon, relatively low temperature and relative humidity inhibit the secondary evaporation effect, thus resulting in lower d-excess values. Although secondary evaporation is lower in the winter months in the dry season, different source areas of water vapor other than the Indian Ocean resulting in rainfall events during this season leads to higher d-excess. However, the highest d-excess values observed during the summer months in the dry season are a result of a combination of rainfall source areas originating from conventional monsoon source - the Bay of Bengal and the effect of secondary evaporation.

\section{Altitude effects}

Monthly isotopic gradients were calculated for Shikarpur and Banlek catchments to estimate altitude effects and to aid in delineating recharge areas of springs under investigation. Variations of $\delta^{18} \mathrm{O}, \delta \mathrm{D}$ and d-excess in rainfall samples at multiple elevations were aggregated to monthly scale (Table 2). There is depletion of heavy isotopes of oxygen $\delta^{18} \mathrm{O}$ and hydrogen $\delta \mathrm{D}$ with increase in altitude observed in Shikarpur for all months under consideration. The decrease in isotopic ratios was not consistent across the elevation zones in both study catchments; moreover, in Shikarpur, the sampling location at 2,243 m, located on the northeast facing side of the hill, has different isotopic composition than the sampling locations at 2,364, 2,063 and 1,954 $\mathrm{m}$ on the Southwest face of the hill. In Banlek, rainfall samples collected at $733 \mathrm{~m}$ showed more depleted isotopic composition than the samples collected at 808 and $936 \mathrm{~m}$. An average isotopic gradient of $-0.25 \%$ ol $100 \mathrm{~m}$ for $\delta^{18} \mathrm{O}$ and $-1.73 \%$ o $/ 100 \mathrm{~m}$ for $\delta \mathrm{D}$ was estimated for Shikarpur, and $-0.12 \% / 100 \mathrm{~m}$ for $\delta^{18} \mathrm{O}$ and $-1.5 \% \mathrm{o} / 100 \mathrm{~m}$ for $\delta \mathrm{D}$ for the Banlek catchment. The average monthly variations of altitude-induced effects on $\delta^{18} \mathrm{O}$ and $\delta \mathrm{D}$ composition across all rainfall samples are shown in Fig. 8. In the case of Shikarpur, the rate of decrease in the isotopic composition is more prominent in September and least in October 2016. In Banlek, the rate of $\delta \mathrm{D}$ decrease with altitude is prominent in September, similar to the findings in Shikarpur, but $\delta^{18} \mathrm{O}$ altitudinal effects were pronounced in July and less variable in August 2016. 
Table 3 The monthly average $\delta^{18} \mathrm{O}, \delta \mathrm{D}$ and d-excess values of precipitation in the study area at different attitudes

\begin{tabular}{|c|c|c|c|c|c|c|c|c|}
\hline \multirow[t]{2}{*}{ Month-year } & \multirow[t]{2}{*}{ Parameter } & \multicolumn{4}{|l|}{ Shikarpur } & \multicolumn{3}{|l|}{ Banlek } \\
\hline & & $2,364 \mathrm{~m}$ & $2,243 \mathrm{~m}^{\mathrm{a}}$ & $2,063 \mathrm{~m}$ & $1,954 \mathrm{~m}$ & $936 \mathrm{~m}$ & $808 \mathrm{~m}$ & $733 \mathrm{~m}$ \\
\hline \multirow[t]{3}{*}{ Jul-16 } & $\delta^{18} \mathrm{O}(\% \circ)$ & -12.15 & - & -10.79 & -10.65 & -10.12 & -9.19 & -9.49 \\
\hline & $\delta \mathrm{D}(\% o)$ & -85.98 & - & -75.85 & -74.06 & -69.78 & -66.75 & -69.36 \\
\hline & d-excess $(\% o)$ & 11.25 & - & 10.44 & 11.11 & 11.17 & 6.81 & 6.56 \\
\hline \multirow[t]{3}{*}{ Aug-16 } & $\delta^{18} \mathrm{O}(\% \circ)$ & -13.52 & -11.22 & -12.81 & -12.51 & -9.45 & -9.40 & -9.81 \\
\hline & $\delta \mathrm{D}(\%)$ & -99.09 & -73.12 & -94.26 & -92.96 & -85.99 & -66.75 & -72.37 \\
\hline & d-excess $(\% o)$ & 9.04 & 16.65 & 8.23 & 7.12 & 8.76 & 8.42 & 6.09 \\
\hline \multirow[t]{3}{*}{ Sep-16 } & $\delta^{18} \mathrm{O}(\% o)$ & -11.60 & -8.86 & -10.22 & -9.93 & -9.18 & -8.85 & -9.52 \\
\hline & $\delta \mathrm{D}(\% o)$ & -81.88 & -63.47 & -72.51 & -67.78 & -64.25 & -65.46 & -67.09 \\
\hline & d-excess $(\% o)$ & 10.88 & 7.44 & 9.23 & 11.67 & 9.19 & 5.37 & 9.04 \\
\hline \multirow[t]{3}{*}{ Oct-16 } & $\delta^{18} \mathrm{O}(\% o)$ & -9.24 & -8.14 & -8.82 & -9.20 & -6.51 & -7.40 & -7.05 \\
\hline & $\delta \mathrm{D}(\% \circ)$ & -61.02 & -53.40 & -58.90 & -64.47 & -42.52 & -51.41 & -47.25 \\
\hline & d-excess $(\% o)$ & 12.91 & 11.71 & 11.68 & 9.14 & 9.53 & 7.83 & 9.15 \\
\hline \multirow[t]{3}{*}{ Jan-17 } & $\delta^{18} \mathrm{O}(\% o)$ & -11.67 & -10.96 & -10.62 & -10.80 & -3.56 & -3.56 & -3.68 \\
\hline & $\delta \mathrm{D}(\% o)$ & -80.91 & -74.23 & -70.83 & -71.09 & -14.41 & -14.8 & -15.24 \\
\hline & d-excess $(\% o)$ & 12.43 & 13.48 & 14.12 & 15.33 & 14.10 & 13.68 & 14.23 \\
\hline \multirow[t]{3}{*}{ Feb-17 } & $\mathrm{d}^{18} \mathrm{O}(\% 0)$ & -0.40 & 2.69 & 0.48 & 0.77 & - & - & - \\
\hline & $\delta \mathrm{D}(\% o)$ & 14.26 & 33.08 & 19.54 & 21.57 & - & - & - \\
\hline & d-excess $(\% o)$ & 17.48 & 11.60 & 15.68 & 15.40 & - & - & - \\
\hline \multirow[t]{3}{*}{ Mar-17 } & $\delta^{18} \mathrm{O}(\% o)$ & 1.97 & 1.08 & 1.27 & 1.48 & - & - & - \\
\hline & $\delta \mathrm{D}(\% o)$ & 31.12 & 31.44 & 31.68 & 34.84 & - & - & - \\
\hline & d-excess $(\% o)$ & 15.40 & 22.83 & 21.56 & 22.97 & - & - & - \\
\hline
\end{tabular}

${ }^{\text {a } I n d i c a t e s ~ r a i n f a l l ~ s a m p l i n g ~ l o c a t i o n ~ o n ~ n o r t h e r n ~ h i l l ~ f a c e ~}$

\section{Delineation of spring recharge elevations in the study catchments}

The estimated altitudinal gradient for $\delta^{18} \mathrm{O}$ and $\delta \mathrm{D}$ in rainfall has been used to delineate the recharge areas of aquifers (Longinelli and Selmo 2003) feeding the spring system in Shikarpur and Banlek catchments. The altitude-effect estimates are a vital tool to delineate spring recharge areas in both study catchments because of the steep slopes. The recharge elevations for Shikarpur and Banlek springs were estimated from the Shuttle Radar Topography Mission (STRM) 30-m digital elevation model (DEM) using the linear relationship summarized in Table 4. Figure 10 visualizes the extent of suitable recharge zones to implement climate-resilient recharge interventions in the catchments to augment spring flow. The estimated mean recharge elevation ranges for springs SS-1 and SS-2 in Shikarpur fed by unconfined groundwater sources are 2,600-2,700 m (Fig. 9a-b). Similarly, for unconfined groundwater-fed springs, BS-2 and BS-3 in Banlek, the recharge elevation range is 1,000 $1,100 \mathrm{~m}$ asl (Fig. 9c-d). The estimated recharge elevation range for spring SS-3 in Shikarpur is 2,720-2,760 m asl, which is higher than the maximum elevation of $2,681 \mathrm{~m}$ asl within the catchment.
All estimated recharge zones are located at elevations higher than that of the rainfall sampling locations. Such values reiterates the findings from a hydrometric analysis that the spring source SS-3 possibly emerges from discontinuities in the limestone formation or from the contact of the phyllite and the karstic limestone in the form of a spring, and the pathways have longer residence times. The difference in dominant water sources contributing to spring discharge also explains the difference in isotopic composition between SS-3 and springs SS-1 and SS-2. Similarly, recharge zones estimated from $\delta \mathrm{D}$ data for Banlek catchment provided unreasonable values for all the springs, indicating a need for more sampling. By combining insights from the hydrometric and isotope analysis, it was decided that the isotopic sampling extent within the springsheds was not sufficient to demarcate the recharge zone range estimates of springs BS-1 and BS- 4 fed by discontinuities in quartzite and phyllite formations in Banlek, and, spring SS-3 from the limestone and phyllite formations in Shikarpur. Surveys to gather additional hydro-geological information on sub-surface connectivity in these two pilot sites were recommended to DFSC for further assessment.

It is also possible that the recharge areas for these springs lie in higher areas beyond the immediate catchment, but connected to the same mountain range. Especially in Shikarpur, 
Fig. 7 Monthly averaged dexcess values of precipitation samples collected in Shikarpur in 2016 and 2017

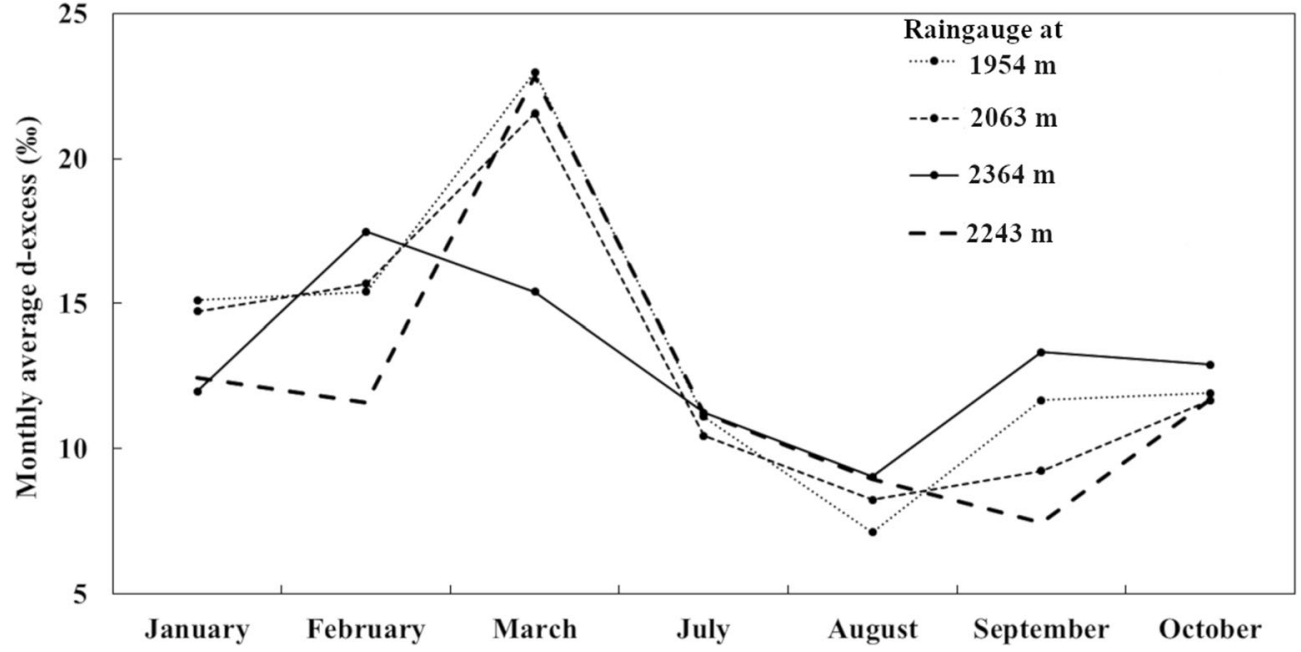

karst topography can support such long-range subsurface aquifer connectivity. To narrow down the dominant process supplementing spring flow, further detailed hydrogeological mapping of the headwater catchments in Shikarpur is necessary.

The estimated mean recharge elevation zones for springs in Shikarpur catchment $(\sim 2,600-2,700 \mathrm{~m})$ is located in the same mountain range but $2.3 \mathrm{~km}$ east of springs SS-1 and SS-2, far from the immediate catchment. In contrast, the estimated recharge elevation zones overlap with the planned interventions in Banlek catchment. Interventions such as social fencing,

Fig. 8 Monthly variations in the rate of change in $\mathbf{a} \delta^{18} \mathrm{O}$ and $\mathbf{b} \delta \mathrm{D}$ composition with altitude (\%o per $100 \mathrm{~m}$ ) across all rainfall samples piped diversion, and plantation are proposed for Shikarpur, while afforestation, grazing management, gully protection, on-farm conservation measures, recharge ponds, and source protection are proposed for spring management in Banlek. The estimated elevation range in the two study catchments will support the ranking of planned climate resilient interventions under the BCRWME project. Detailed hydrogeological characterization of estimated recharge elevation range in both the catchments will provide additional information needed to prioritize the location for planned interventions.

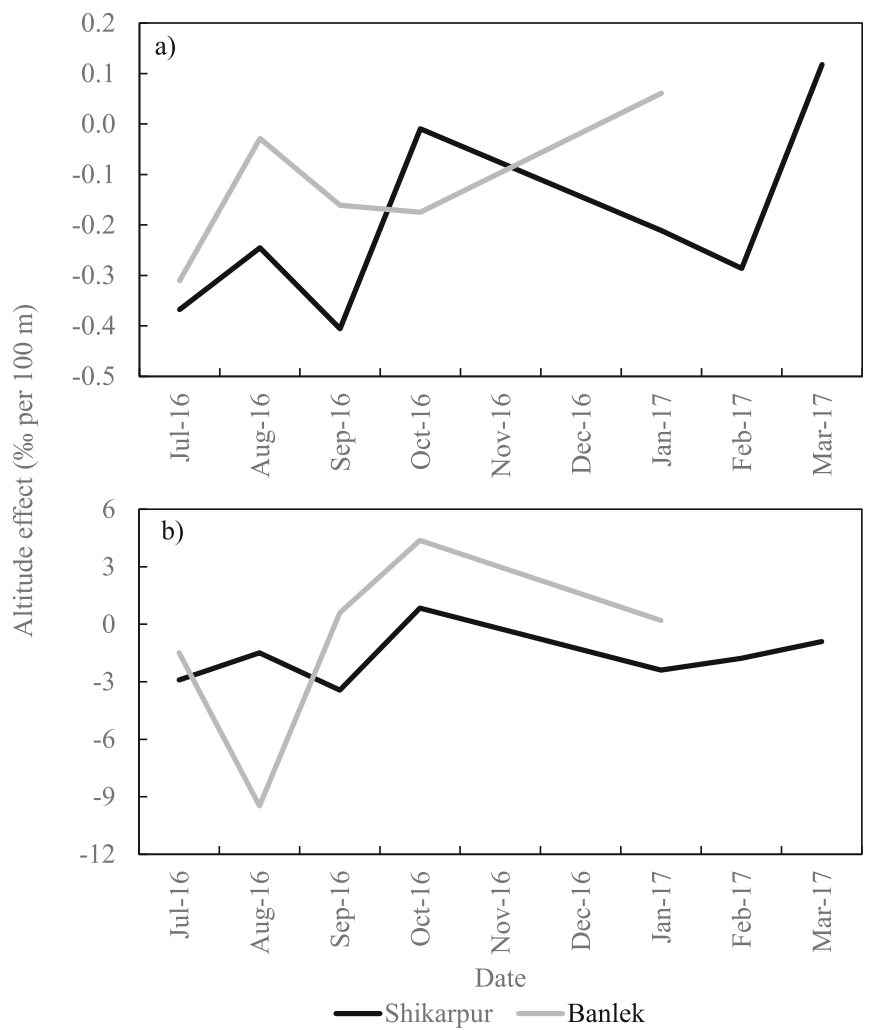


Table 4 Recharge elevations for springs in Shikarpur and Banlek based on the altitudinal gradient of isotopic compositions

\begin{tabular}{|c|c|c|c|c|c|c|}
\hline \multirow[t]{2}{*}{ Catchment } & \multicolumn{2}{|c|}{ Springs } & \multirow[t]{2}{*}{ Sample $\delta^{18} \mathrm{O}(\% o)$} & \multirow[t]{2}{*}{ Sample $\delta \mathrm{D}(\% \circ)$} & \multicolumn{2}{|c|}{ Recharge elevation (m asl) } \\
\hline & ID & Elevation (m asl) & & & Derived from $\delta^{18} \mathrm{O}$ & Derived from $\delta \mathrm{D}$ \\
\hline \multirow[t]{2}{*}{ Shikarpur } & SS-1 & 2,086 & -8.94 & -59.77 & 2,598 & 2,597 \\
\hline & SS-2 & 2,183 & -8.95 & -61.02 & 2,601 & 2,683 \\
\hline \multirow[t]{2}{*}{ Banlek } & BS-2 & 822 & -9.10 & -64.61 & 1,075 & - \\
\hline & BS-3 & 832 & -9.18 & -65.56 & 1,105 & - \\
\hline
\end{tabular}

\section{Discussion}

Precipitation from Southwest monsoon dominates both the catchments. Precipitation in dry season, including snow events, is more common in Shikarpur than Banlek, where rainfall is the only form of precipitation. This rainfall variation is attributed to the difference in topography and orographic effects governing the two small catchments located $21 \mathrm{~km}$ apart with $1,300 \mathrm{~m}$ mean elevation difference. Numerous studies have addressed the altitudinal effect on frequency, intensity and magnitude of rainfall events in the Hindu Kush Himalayas (Bookhagen and Burbank 2010; Palazzi et al. 2013). Specifically, the orographic effect of precipitation in upper, middle and lower Western Himalayan ranges results in significant differences in rainfall patterns with altitude across the region (Singh et al. 1995; Singh and Kumar 1997).

All springs in Banlek and Shikarpur considered in this study are contact springs, which arise at the interface between two strata when the permeability of the lower stratum is relatively lower than that of the top stratum allowing water to flow horizontally and emerge at an outlet (Okwany and Khadka 2016). The three Shikarpur springs (SS-1, SS-2, and SS-3; Fig. 1a) emerge between the limestone and underlying quartzite and phyllite formations. With an inclination towards the south, the upper limestone forms the aquifer system for springs. The upper limestone has well developed joint sets and various caves. The water infiltrating through the limestone initially flows along the inclination of the rock towards the SW and emerges along the contact of the phyllite and the karstic limestone in the form of springs. Banlek spring-1 (BS1; Fig. 1b) similarly originates in the basal slopes near the contact of colluvium soil and fractured quartzite. Springs BS-2 and BS-3 located at the toe end of the colluvium deposits, and BS-4 located further upstream, are a result of the contact between the unconsolidated porous colluvium deposits and the relatively less porous bedrock layer.

Recharge from rainfall events contributes significantly to springs SS-1, SS-2, BS-1, which is evident from their fast response indicating direct recharge from colluvial deposits made of angular fragments of quartzite and phyllite in Banlek, and, of limestone and phyllite in Shikarpur. Apparent lack of rainfall response in the remaining springs signifies sources possibly arising out of discontinuities in the limestone formation in Shikarpur and heavily weathered quartzite formations in Banlek. Deeper groundwater aquifers, connected through fissures and fractures, were observed in the hydrogeological survey. Seasonal variations in the isotopic composition of rainfall in both catchments indicate that maximum enriched rainfall events occurred during dry season, consistent with previous studies in the Himalayan region, which have indicated different water vapor sources of monsoon and dry season rain (Kumar et al. 2010b). The derived LMWL for rainfall in Shikarpur and Banlek follows close resemblance to studies conducted in similar climatic and physiographic region in the Western Himalayas (Bartarya et al. 1995; Ramesh and Sarin 1992). The isotopic signature of the springs in Shikarpur and Banlek are located close to catchment LMWL, indicating the contribution of recharge fed from rainfall.

The altitude effect of $-0.25 \%$ or $\delta^{18} \mathrm{O}$ estimated for springs in Shikarpur is significantly lower than values reported in other studies in Western Himalayan range $(-0.36 \%$, Kumar et al. 2010b; $-0.38 \%$, Ramesh and Sarin 1992; $-0.5 \%$, Navada et al. 1986); however, the Banlek altitude effect of $-0.12 \% / 100 \mathrm{~m}$ for $\delta^{18} \mathrm{O}$ agrees with estimates by Bartarya et al. $1995(-0.14 \%$ o). The altitude effect of -0.2 to $1.1 \%$ / $100 \mathrm{~m}$ for $\delta^{18} \mathrm{O}$ has been observed in other mountainous locations around the world (Kumar et al. 2010b), providing validity to the estimates for Shikarpur. The LWML for the two catchments closely resembles the GWML and LWML in similar areas, and suggests that the isotopic compositions are reasonable estimates despite the inherent uncertainties. It can also be inferred from Fig. 8 that the altitudinal effects do not show strong seasonality and are dominated by the source, amount and trajectory of the air mass bringing the precipitation (Jeelani et al. 2010).

Difficult terrain impeding access to the spring source location, sampling points located some distance away from spring sources with potential mixing of surface runoff, and the piped nature of spring systems for domestic use, may impart potential sources of error into the samples collected for isotopic assessment. Thus, the sampling locations are located downstream of the spring source, which increases the possibility of change in isotopic signature due to evaporation/condensation, 
Shikarpur
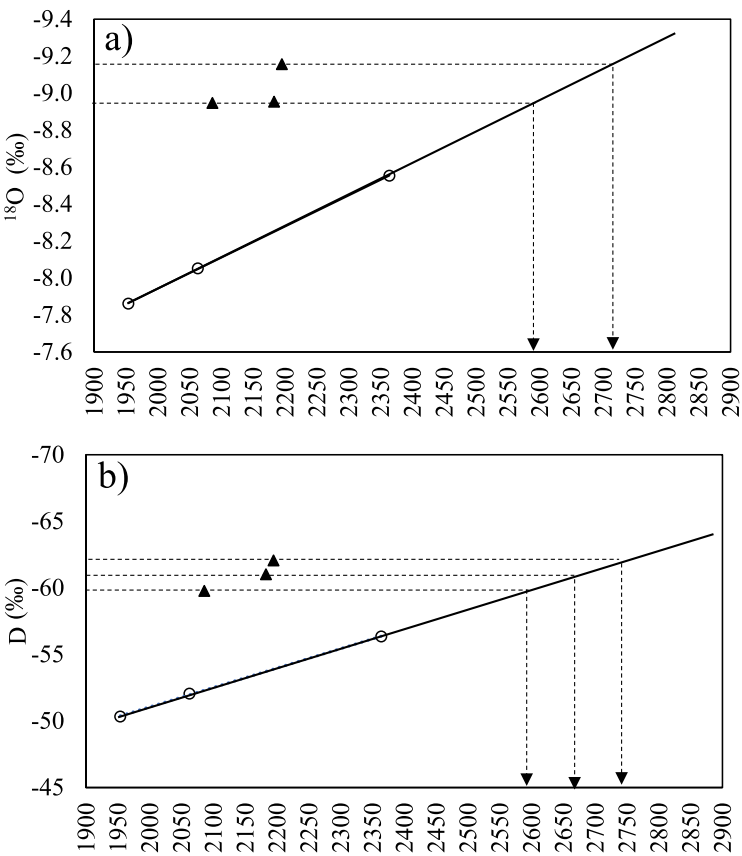

Recharge elevation ( $\mathrm{m}$ asl)
Banlek
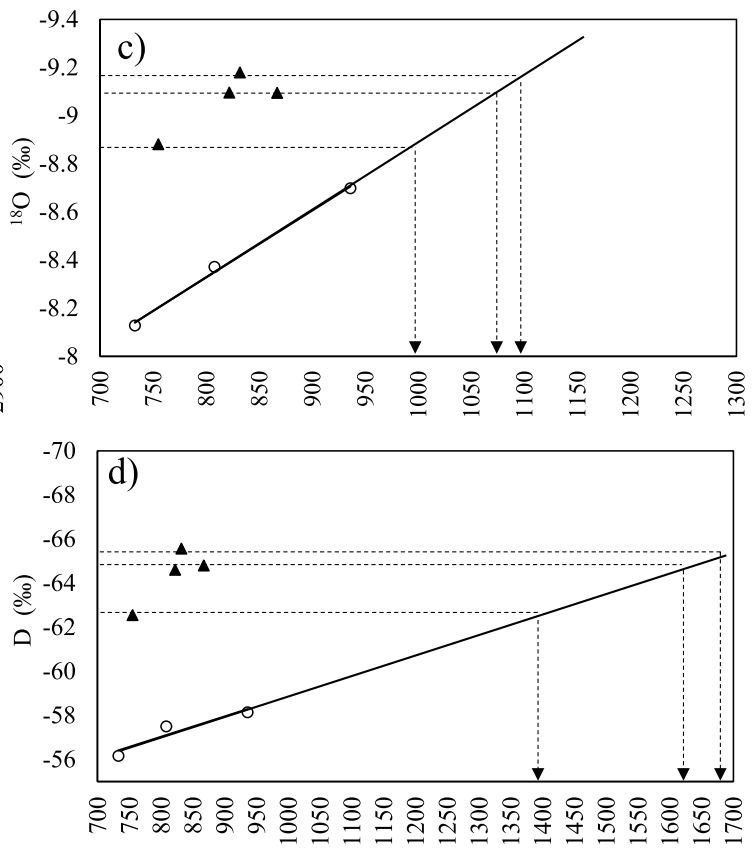

Recharge elevation ( $\mathrm{m}$ asl)

Fig. 9 Weighted mean $\delta^{18}$ Oand $\delta \mathrm{D}$ values of rainfall vs altitude showing the estimated mean recharge elevations of springs in $\mathbf{a}-\mathbf{b}$ Shikarpur and $\mathbf{c}-\mathbf{d}$ Banlek catchments. Triangles indicate springs and circles indicate rainfall samples

oxidation or mixing with surface runoff. Limited rainfall data in Banlek due to instrumentation failure made it harder to discern patterns and identify dependencies between spring flow and rainfall during isotope sampling. While it is useful to expand isotopic sampling to include higher elevations outside the drainage divide, the
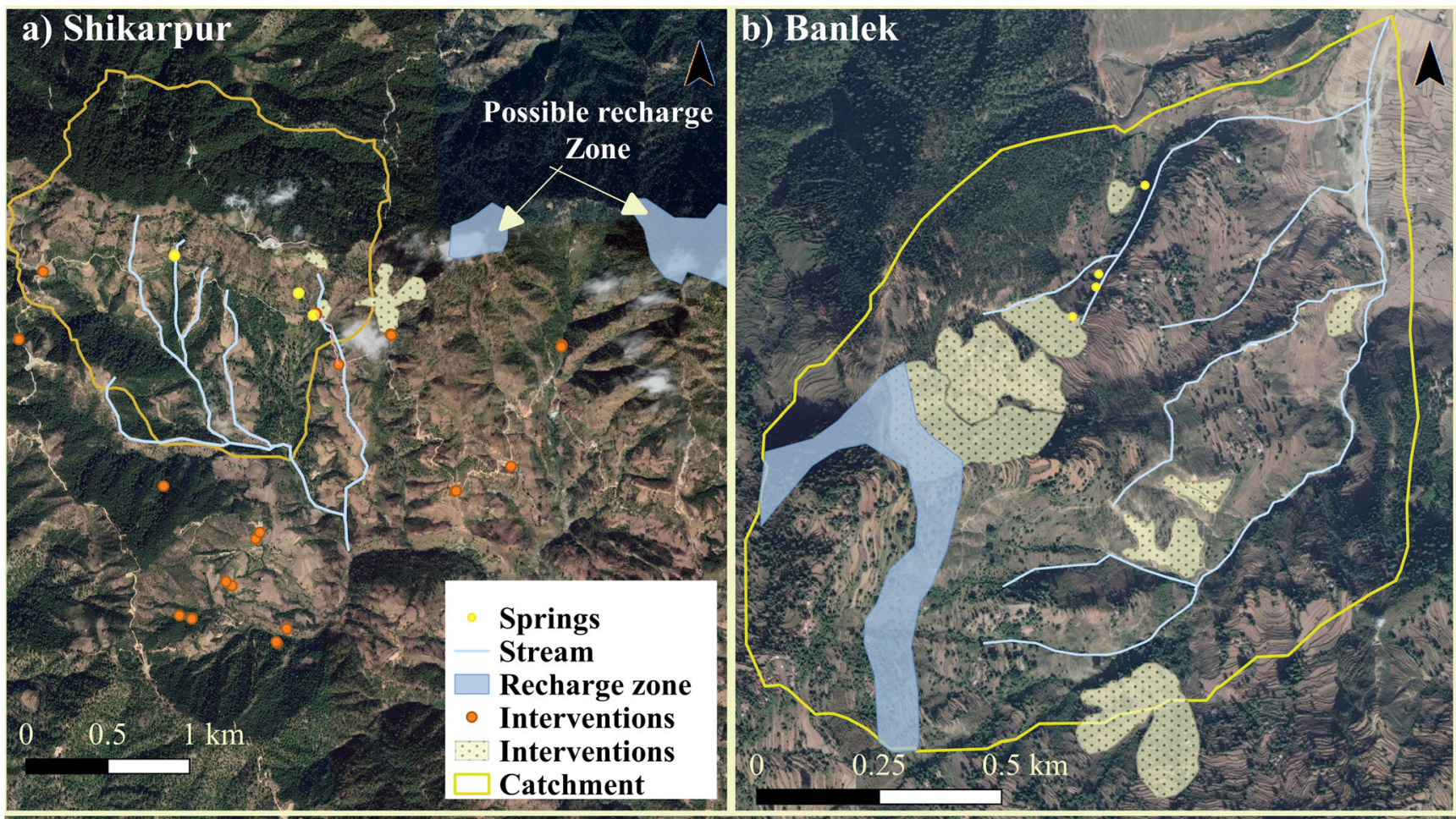

Fig. 10 Location of estimated recharge zones and planned interventions a) Shikarpur and b) Banlek 
expensive nature of isotope analysis limit the number of samples.

The hydrogeological survey of Banlek and Shikarpur lend further evidence to the delineated recharge zones. The recharge zones in Banlek fall within the rich porous colluvium deposits with gentler slopes conducive for infiltration as they increase residence time. In Shikarpur, springs are located at higher elevations on a steep slope, where the dominant recharge mechanism is through fissures and fractures and not through the unconfined aquifer; thus, the isotope-based elevation zones at the ridges of the hill far from the Shikarpur appear justified for recharging springs originating in surface water divides and subsurface fractures and fissures. In addition, springs SS-1, SS-2, BS-2, and BS-3 are contact springs lying at relatively porous upper geological layers forming the unconfined stratum. Springs SS-3 and BS-1, identified as potentially fed by deeper aquifers, lie in basal areas dominated by underlying relatively impervious phyllite and quartzite layers in Shikarpur and bedrock in Banlek respectively. Spring BS-4 in Banlek, located at the end of porous colluvium soil deposited by a previous landslide, should ideally be highly sensitive to rainfall, but such rainfall response is absent in flow measurements.

The spring recharge zonation clearly signifies the difference in the surface water and subsurface divide even in a small headwater mountainous catchment like Shikarpur. Similar to Banlek, springs in Shikarpur showing fast response to the rainfall and located within the demarcated springshed boundary, are easier to augment using planned interventions. The identified recharge zone for Shikarpur, extending beyond the surface-water catchment, suggests that recharge interventions for water augmentation must be implemented beyond the current pilot area. These recharge zones, transcending the local village boundary in which the spring system is located, pose practical challenges in implementation and maintenance of the recharge interventions. Such practical considerations imply that recharge interventions are better suited in Banlek. Other proposed interventions such as piped diversions and focus on increasing water-use efficiency is recommended for Shikarpur. Field knowledge needs to be combined with evidence-based recharge zones identified using isotopes for the success of chosen interventions.

\section{Conclusion}

The spring recharge areas in two mountainous catchments located in Far-Western Nepal, Shikarpur and Banlek, were delineated by comparing the isotopic ratios of $\delta^{18} \mathrm{O}$ and $\delta \mathrm{D}$ in precipitation with springs. Based on the observed rainfall responses in the spring flow measurements, sample sites were categorized into groups fed by unconfined groundwater (SS-1, SS-2, BS-2, and B-3) and the other sites by perennial groundwater sources or recharge locations farther away (SS3 , BS-1, and BS-4). The isotopic composition of rainfall from multiple elevations in the two catchments indicated distinct seasonal patterns with higher enriched values observed during the dry season months. Such seasonality confirms with other studies that the source of water vapor for rainfall in monsoon and dry season is different. The isotopic signature of springs did not show apparent spatiotemporal variations observed in the rainfall events, but values located close to the LMWL indicate a dominant contribution from rainfall. The isotopic signatures of rainfall and spring samples are comparable to previous studies.

The recharge elevation range of 1,000-1,100 $\mathrm{m}$ asl for springs in Banlek, falling within the catchment boundary, and 2,600-2,700 $\mathrm{m}$ asl for springs in Shikarpur, were estimated. It was observed that, unlike in Banlek, the recharge zone for springs in Shikarpur lies outside the surface-water catchment boundary, necessitating conservation measures beyond the demarcated drainage boundary. In Banlek, the small and gentle sloped topographic plateau located upstream of the springs supports the recharge elevation zones identified by the isotope analysis. The demarcated recharge zones will support the BCRWME project to prioritize interventions based on their scientific and practical viability to suit site-specific conditions; furthermore, categorizing springs fed by the unconfined aquifer in each catchment can assist in augmenting recharge with climate-resilient interventions. Of the proposed interventions for Shikarpur, piped diversion may be a better investment. For Banlek, afforestation, grazing management, gully protection, on-farm conservations and recharge ponds should be concentrated in identified recharge zones. For the first time, this isotopic study provided an evidence base to derive quantitative information on spring recharge areas in small mountainous catchments in Far-Western Nepal region. This successful pilot study will be scaled up by the DFSC in future iterations of the project to delineate spring recharge zones and design interventions to build resiliency in springs.

Funding information The authors acknowledge the Climate Investment Fund, Nordic Development Fund and the Asian Development Bank for funding this work as part of the Strategic Technical Assistance project GRANT: 0358-NEP-Building Climate Resilience of Watersheds in Mountain Eco-regions (BCRWME)-led by the Department of Forest and Soil Conservation (DFSC), previously Department of Soil Conservation and Watershed Management (DSCWM), Government of Nepal) - under the sub-package Watershed Hydrology Impact Monitoring Research.

Open Access This article is distributed under the terms of the Creative Commons Attribution 4.0 International License (http:// creativecommons.org/licenses/by/4.0/), which permits unrestricted use, distribution, and reproduction in any medium, provided you give appropriate credit to the original author(s) and the source, provide a link to the Creative Commons license, and indicate if changes were made. 


\section{References}

Bartarya SK, Bhattacharya SK, Ramesh R, Somayajulu BLK (1995) $\delta^{18} \mathrm{O}$ and $\delta \mathrm{D}$ systematics in the surficial waters of the Gaula River catchment area, Kumaun Himalaya. Indian J Hydrol 167:369-379

Bookhagen B, Burbank DW (2010) Toward a complete Himalayan hydrological budget: spatiotemporal distribution of snowmelt and rainfall and their impact on river discharge. J Geophys Res Earth Surf 115. https://doi.org/10.1029/2009JF001426

Chinnasamy P, Prathapar SA (2016) Methods to investigate the hydrology of the Himalayan springs: a review. IWMI Working Paper 169, International Water Management Institute, Colombo, Sri Lanka, 28 pp. https://doi.org/10.5337/2016.205

Chowdhury A, Jha MK, Chowdary VM (2010) Delineation of groundwater recharge zones and identification of artificial recharge sites in West Medinipur District, West Bengal, using RS, GIS, and MCDM techniques. Environ Earth Sci 59:1209-1222

Clark ID, Fritz P (1997) Environmental isotopes in hydrogeology. Lewis, Boca Raton, FL, 328 pp

Craig M (1961) Isotopic variation in meteoric waters. Science 133:17021703

Dansgaard W (1964) Stable isotopes in precipitation. Tellus 16:436-438

Datta PS, Tyagi SK, Chandrasekhran H (1991) Factors controlling stable isotope composition of rainfall in New Delhi. J Hydrol 128:223-236

Dixit A, Khadka S (2013) Web of resilience: cross-scale implications of forest and water management for adaptation-mitigation and food security in the Nepal Himalayas. http://hdl.handle.net/10625/ 52759. Accessed April 2019

Fetter CW (2001) Applied hydrogeology, 4th edn. Prentice Hall, Englewood Cliffs, NJ

Florea L, Bird B, Lau JK et al (2017) Stable isotopes of river water and groundwater along altitudinal gradients in the high Himalayas and the eastern Nyainqentanghla Mountains. J Hydrol Reg Stud 14:3748. https://doi.org/10.1016/j.ejrh.2017.10.003

Fontes JC, Letolle R, Oliver H, Ravoux B (1967) Oxygene18 et tritium dans le basin d'Evian [Oxygen 18 and tritium in the Evian Basin]. In: Proceedings of symposium on isotopes in hydrology, International Atomic Energy Agency, Vienna, $401 \mathrm{pp}$

Froehlich K, Gibson JJ, Aggarwal P (2002) Deuterium excess in precipitation and its climatological significance. Proc. Int. Conf. on Study of Environmental Change Using Isotope Techniques, C\&S Papers Series 13/P, International Atomic Energy Agency, Vienna, 54-66 pp

Garzione CN, Quade J, DeCelles PG, English NB (2000) Predicting paleoelevation of Tibet and the Himalaya from $\delta 180$ vs altitude gradients in meteoric water across the Nepal Himalaya earth. Planet Sci Lett 183(1-2):215-229. https://doi.org/10.1016/S0012$821 \mathrm{X}(00) 00252-1$

Gat JR (1971) Comments on the stable isotope method in regional groundwater investigations. Water Resour Res 7(4):980-993. https://doi.org/10.1029/WR007i004p00980

Gat JR, Bowser CJ, Kendall C (1994) The contribution of evaporation from the Great Lakes to the continental atmosphere: estimate based on stable isotope data. Geophys Res Lett 21: https://doi.org/10. 1029/94GL00069

Gonfiantini R (1981) The $\delta$-notation and the mass spectrometric measurement techniques. In: Stable isotope hydrology: deuterium, and oxygen-18 in the water cycle. Technical Reports Series no. 210, International Atomic Energy Agency, Vienna

Government of Sikkim (2014) Dhara Vikas handbook: a user manual for springshed development to revive Himalayan springs. Government of Sikkim, Gangtok, India

IDS-Nepal, PAC and GCAP (2014) Economic impact assessment of climate change in key sectors in Nepal. IDS-Nepal, MoSTE, Kathmandu, Nepal. http://www.vfmadaptation.com/EIAsummary_sharing_final-low-resolution.pdf. Accessed April 2019
Jeelani G, Bhat NA, Shivanna K (2010) Use of $\delta^{18} \mathrm{O}$ tracer to identify stream and spring origins of a mountainous catchment: a case study from Liddar watershed, western Himalaya, India. J Hydrol 393(34):257-264. https://doi.org/10.1016/j.jhydrol.2010.08.021

Jeelani G, Kumar US, Bhat NA, Sharma S, Kumar B (2015) Variation of $\delta^{18} \mathrm{O}, \delta \mathrm{D}$ and $3 \mathrm{H}$ in karst springs of South Kashmir, western Himalayas (India). Hydrol Process 29(4):522-530. https://doi.org/ 10.1002/hyp. 10162

Jeelani G, Shah RA, Deshpande RD et al (2017) Distinguishing and estimating recharge to karst springs in snow and glacier dominated mountainous basins of the western Himalaya, India. J Hydrol 550: 239-252. https://doi.org/10.1016/j.jhydrol.2017.05.001

Kresic N, Bonacci O (2010) Spring discharge hydrograph. In: Kresic N, Stevanovic Z, (eds) Groundwater hydrology of springs: engineering, theory, management and sustainability. Butterworth-Heinemann, Oxford, UK, pp 129-163

Kumar B, Rai SP, Kumar US et al (2010a) Isotopic characteristics of Indian precipitation. Water Resour Res 46. https://doi.org/10.1029/ 2009WR008532

Kumar US, Kumar B, Rai SP, Sharma S (2010b) Stable isotope ratios in precipitation and their relationship with meteorological conditions in the Kumaon Himalayas, India. J Hydrol 391(1-2):1-8. https://doi. org/10.1016/j.jhydrol.2010.06.019

Longinelli A, Selmo E (2003) Isotopic composition of precipitation in Italy: a first overall map. J Hydrol 270:75-88. https://doi.org/10. 1016/S0022-1694(02)00281-0

Mathieu R, Bariac T (1996) An isotopic study (2H and 18O) on water movements in clayey soils under a semiarid climate. Water Resour Res 32:779-789

Mekonnen MM, Hoekstra AY (2016) Four billion people facing severe water scarcity. Sci Adv 2:e1500323. https://doi.org/10.1126/sciadv. 1500323

Merz J, Nakarmi G, Weingartner R (2003) Potential solutions to water scarcity in the rural watersheds of Nepal's Middle Mountains. Mt Res Dev 23(1):14-18. https://doi.org/10.1659/02764741(2003)023[0014:PSTWSI]2.0.CO;2

Navada SV, Jain SK, Shivanna K, Rao SM (1986) Application of environmental isotopes in groundwater hydrology. Indian J Earth Sci 13(3-3):223-234

Negi GCS, Joshi V (1996) Geohydrology of springs in a mountain watershed: the need for problem-solving research. Curr Sci 71(10): $772-776$

Negi GCS, Joshi V (2002) Drinking water issues and development of spring sanctuaries in a mountain watershed in the Indian Himalaya. Mt Res Dev 22:29-31. https://doi.org/10.1659/02764741(2002)022[0029:DWIADO]2.0.CO;2

O'Driscoll MA, DeWalle DR, McGuire KJ, Gburek WJ (2005) Seasonal $18 \mathrm{O}$ variations and groundwater recharge for three landscape types in central Pennsylvania, USA. J Hydrol 303:108-124

Oki BET, Arnell NW, Benito G, Cogley JG, Döll P, Jiang T, Mwakalila SS (2014) Freshwater resources. In: Climate Change 2014: impacts, adaptation, and vulnerability. In: Field CB, Barros VR, Dokken DJ, Mach KJ, Mastrandrea MD, Bilir TE, Chatterjee M, Ebi KL, Estrada YO, Genova RC, Girma B, Kissel ES, Levy AN, MacCracken S, Mastrandrea PR, White LL (eds) Part A: global and sectoral aspects. Contribution of Working Group II to the Fifth Assessment Report of the Intergovernmental Panel on Climate Change, Cambridge University Press, Cambridge, UK, pp 229-269

Okwany R, Khadka A (2016) Small catchment water resource assessment as a driver for watershed management plans: a case study of Banlek and Shikarpur springsheds in Far-West Nepal. International Water Management Institute, Kathmandu, Nepal

Palazzi E, von Hardenberg J, Provenzale A (2013) Precipitation in the Hindu-Kush Karakoram Himalaya: observations and future scenarios. J Geophys Res Atmos 118:85-100. https://doi.org/10.1029/ 2012JD018697 
Palmer MA, Reidy Liermann CA, Nilsson C, Flörke M, Alcamo J, Lake PS, Bond N (2008) Climate change and the world's river basins: anticipating management options. Front Ecol Environ 6:81-89

Price RM, Swart PK (2006) Geochemical indicators of groundwater recharge in the surficial aquifer system, Everglades National Park, Florida, USA. Geol Soc Am Spec Pap 404:251-266

Racoviteanu AE, Armstrong R, Williams MW (2013) Evaluation of an ice ablation model to estimate the contribution of melting glacier ice to annual discharge in the Nepal Himalaya: glacial contributions to annual streamflow in Nepal Himalaya. Water Resour Res 49:51175133. https://doi.org/10.1002/wrcr.20370

Ramesh R, Sarin MM (1992) Stable isotope study of the Ganga (Ganges) River system. J Hydrol 139:49-58

Rozanski KL, Araguas-Araguas GR (1993) Isotopic patterns in modern global precipitation. In: Swart PK (ed) Climate change in continental isotopic records. Geophysics Monograph Series, vol. 78, pp 1-36

Scanlon BR, Healy RW, Cook PG (2002) Choosing appropriate techniques for quantifying groundwater recharge. Hydrogeol J 10:18 39. https://doi.org/10.1007/s10040-001-0176-2

Shah RA, Jeelani G, Jacob N (2017) Estimating mean residence time of karst groundwater in mountainous catchments of Western Himalaya, India. Hydrol Sci J 62:1230-1242. https://doi.org/10.1080/ 02626667.2017.1313420

Sharma KP, Vorosmarty CJ, Moore Iii B (2000) The sensitivity of the Himalayan hydrology to land-use and climatic changes. Clim Chang 47(1-2):117-139

Sharma B, Nepal S, Gyawali D, Pokharel GS, Wahid SM, Mukherji A, Acharya S, Shrestha AB (2016) Springs, storage towers, and water conservation in the mid-hills of Nepal. ICIMOD Working Paper 2016/3, Nepal Water Conservation Foundation and International Center for Mountain Development, Kathmandu, Nepal

Siddiqui S, Bharati L, Pant M, Gurung P, Rakhal B (2012) Nepal: building climate resilience of watersheds in mountain eco-regions: climate change and vulnerability mapping in watersheds in middle and high mountains of Nepal. ADB Technical Assistance Consultant's
Report for Department of Soil Conservation and Watershed Management (DSCWM)-Government of Nepal, Kathmandu, Nepal. Asian Development Bank), Manila, Philippines, 96 pp. http://www.adb.org/sites/default/files/project-document/73085/ 44214-023-nep-tacr.pdf. Accessed March 2019

Singh P, Kumar N (1997) Effect of orography on precipitation in the western Himalayan region. J Hydrol 199(1-2):183-206. https:// doi.org/10.1016/S0022-1694(96)03222-2

Singh P, Ramashastri KS, Kumar N (1995) Topographical influence on precipitation distribution in different ranges of Western Himalayas. Nord Hydrol 26:259-284

Stimson J, Rudolph D, Farvolden F, Frape S, Drimmie R (1993) Causes of groundwater salinization in a low lying area of Cochabamba Valley, Bolivia. Isotope techniques in the study of past and current environmental changes in the hydrosphere and the atmosphere, IAEA-SM-329/26, IAEA, Vienna, pp 185-198

Tambe S, Kharel G, Arrawatia ML, Kulkarni H, Mahamuni K (2012) Reviving dying springs: climate change adaptation experiments from the Sikkim Himalaya. Mt Res Dev 32(1):62-72. https://doi. org/10.1659/MRD-JOURNAL-D-11-00079.1

UNWFP (2014) Climate risk and food security in Nepal: analysis of climate impacts on food security and livelihoods. United Nations World Food Program, Rome

Valdiya KS, Bartarya SK (1989) Diminishing discharges of mountain springs in a part of Kumaun Himalaya. Curr Sci 58(8):417-426

Vashisht AK (2008) Ingenious techniques for irrigation sustainability in Himalayan and Shiwalik foothill regions. Curr Sci 95(12):1688

WECS (2011) Water resources of Nepal in the context of climate change. Water and Energy Commission Secretariat (WECS), Singha Durbar, Kathmandu, Nepal

Wilson AM (2015) Hydrograph separation using hydrochemistry mixing models: an assessment of the Langtang River Basin, Nepal. Geography Graduate Theses and Dissertations 76. University of Colorado, Boulder, CO. https://scholar.colorado.edu/geog_ gradetds $/ 76$ 